\title{
Insertions and Deletions: Evolution in the Assemblage of Vietnamese Food Plants
}

\author{
My Lien Thi Nguyen
}

\section{Research}

\begin{abstract}
An analysis of taxa used and that are salient to Vietnamese in Hawai'i compared with southern Vietnam reflects an evolution of the assemblage of food plants demonstrated by substitutions, insertions, and deletions of plant taxa. Replications occur as the Vietnamese in Hawai'i have access to many similar plant taxa as those in Vietnam, possibly due to the location of Hawai'i as a place where similar food plants can grow and due to a large Asian population. Food plant taxa were elicited from interviews and recorded during participant observations. The current scientific botanical nomenclature and taxonomic groupings, plant life form or part utilized, the southern and many northern Vietnamese vernacular names with diacritical markings, and the English and French translations are provided for over 200 food plants. An introduction to Vietnamese diacritical writing and vernacular botanical nomenclature is included.
\end{abstract}

\section{Introduction}

Despite nearly 30 years of influence on the food, market, and garden flora of the United States, our knowledge of the food plants used by the Vietnamese is only preliminary (Airriess \& Clawson 1994, Kuebel \& Tucker 1988, Nguyen 2003, 2005, Owens 2003). Furthermore, while other waves of Asian immigrants (e.g., Chinese, Japanese, and Filipino) have introduced their foods there are no current published surveys of food plants sold in Asian markets in the United States although there are older reports (Chung \& Ripperton 1929, Miller 1933, Porterfield Jr. 1951).

From recent reports involving Vietnamese economic and ethno- botanical studies in Vietnam (Ogle et al. 2003, Tanaka 2004) and in the United States (Owens 2003, Staples \& Kristiansen 1999), it is evident that there is a need for a reference of accurate scientific and Vietnamese plant names. The main issue is the absence or misuse of diacritics when writing Vietnamese words. If one understands that a single stroke of the pen can change the meaning of a word from "melon fruit" to "coconut palm", one would agree that it is important to not only record, but also to share and report the accurate name. Such is the case with the names of plants in the Vietnamese language. As a native speaker and an ethnobotanist, I contend the unambiguous understanding and use of Vietnamese vernacular botanical nomenclature for laying a solid foundation for the field.

The purposes of this report are: 1) to identify food plants salient to Vietnamese in Hawai' $i$ and southern Vietnam, 2) to analyze the plant taxa elicited through interviews in order to test the hypothesis that an 'evolution' in the assemblage of food plants salient to Vietnamese in Hawai' $i$ has occurred as demonstrated by plant substitutions, insertions, and deletions, and 3) to provide a reference of scientific and vernacular names of food plants used by Vietnamese people that (i) is current in botanical nomenclature and taxonomic groupings, (ii) is accurate in the diacritical and tonal Vietnamese vernacular names of plants, and (iii) provides English and French vernacular

\section{Correspondence}

My Lien Thi Nguyen, Department of Biological Sciences, Wellesley College, 106 Central Street, Wellesley, MA 02481. U.S.A. mylien@wellesley.edu

Ethnobotany Research \& Applications 4:175-201 (2006) 
names for cross-referencing research. I provide information for typing diacritic Vietnamese fonts at the end of this paper to facilitate accurate and efficient research and reporting,

\section{Vietnamese Language and Vernacular Botanical Nomenclature}

\section{The Vietnamese language}

Vietnamese is the national language of the Socialist Republic of Vietnam and of the Kinh or Việt ethnic group that represents the majority of diasporic Vietnamese. Vietnamese is only one of the over 90 languages spoken by the 54 ethnic groups in Vietnam but it is spoken by nearly $90 \%$ of the population. The northern (NV), central, and southern (SV) dialects are reflected by numerous examples of multiple vernacular names for a single subject and pronunciations for a single word. With the Vietnamese diaspora, the language is spoken everywhere they have settled throughout the world (SIL 2004).

\section{Vietnamese diacritics and their importance in plant names}

The Vietnamese language incorporates a system of diacritical marking that are applied to the vowels a, â, à, e, ê $\mathbf{i}, \mathbf{o}, \mathbf{o}, \mathbf{u}, \mathbf{u}$, and $\mathbf{y}$. The alphabet also includes the consonant, "đ." This "đ" is pronounced similarly to the English "d," as in the word "dog." In contrast, the Vietnamese letter "d," while written the same as the English "d," is actually pronounced as the English "z," as in "zebra" (NV) or "y," as in "yellow" (SV). These diacritics are used to designate tones in spoken words and are requisite in distinguishing the meanings of otherwise similarly spelled words (Table 1). This indispensable use of diacritics to distinguish meaning is also present in the Vietnamese botanical nomenclature (Table 2). See Đinh (1976) for an in-depth analysis of the botanical nomenclature, including the Chinese and French influences.

Table 1. Tones and diacritical marks used in Vietnamese writing. Examples of their application for "ma" and the corresponding English translations.

\begin{tabular}{|l|c|l|l|}
\hline Tone & Diacritic & Vietnamese & English $^{\text {a }}$ \\
\hline mid-level & none & ma & funeral \\
\hline high-rising & $\cdot$ & má & mother \\
\hline low-falling & $\cdot$ & mà & but \\
\hline high-rising-glottal & $\sim$ & mã & horse \\
\hline low-falling-rising & $\sim$ & mả & grave \\
\hline low-falling-glottal & $\cdot$ & mạ & rice seedling \\
\hline $\begin{array}{l}\text { aEnglish translation according to the first usage in Nguyễn } \\
\text { and Nhóm's (2000) Vietnamese-English dictionary. }\end{array}$ \\
\hline
\end{tabular}

In fact, it is the French that have been most diligent (for non-Vietnam based scientists) in using diacritics in their Vietnamese botanical research. French researchers compiled extensive Vietnamese botanical literature and specimens due to France's colonization of and economic interests in Vietnam. Vietnamese names were recorded: (1) on many herbarium vouchers collected during botanical explorations (e.g., a rice cultivar (in this case with a French translation): "lúa bông giâu, fleur de múrier" on voucher 14 March 1869, Oryza sativa var. mutica Pierre 122 P!); (2) in publications concerning botany in Vietnam (cf., Crevost et al. 1917-1941, Đinh 1981); and (3) in publications concerning the ethnobotany of the Vietnamese in France (Simon \& Simon-Barouh 1972, Walujo 1985).

Important as it is, few have been as careful in their employ of Vietnamese plant names as the French (Hodel et al. 1999, Kuebel \& Tucker 1988, Nguyen 2003, 2004, 2005). This is notable due to the recent increase of Vietnamese ethnobotanical publications, both from studies in Vietnam (Ireson \& Ireson 1996, Nguyen 2000, Ogle et al. 2003, Tanaka 2004) and in the United States (Airriess \& Clawson 1994, Corlett et al. 2003, Nguyen 2000, Owens 2003, Staples \& Kristiansen 1999). This increase in Vietnamese research is a contribution towards balancing a historically American continent dominated focus in ethnobotanical research publications (American continent $>40 \%$ vs. Asia $<25 \%$ (Cotton 1996)). At this stage in particular, it is counterproductive for progress, to publish reports less than complete with the diacritical language. Reasons for not using diacritics include: (1) confusion regarding their correct application; (2) lack of reliable, comprehensive references to check Vietnamese names; and (3) technology difficulties (i.e., incompatible language programs and formatting difficulties in word processing programs) (personal communication, R. Owens 2003, and G. Staples 2000).

Table 2. Changes in the botanical meaning of the word "dua" with the application of diacritical marks. Example for the consonants, "đ" and "d" and the vowels "u" and "u".

\begin{tabular}{|c|c|c|c|}
\hline $\begin{array}{l}\text { Consonant } \\
\text { and Vowel }\end{array}$ & Diacritic & $\begin{array}{l}\text { Vietnamese } \\
\text { Generic }\end{array}$ & $\begin{array}{l}\text { English or } \\
\text { Latin a }\end{array}$ \\
\hline $\mathbf{d}+u$ & none & đua & to compete \\
\hline$d+u$ & none & dua & no meaning \\
\hline$d+u$ & none & dura $^{a}$ & $\begin{array}{l}\text { Cucumis o } \\
\text { Citrullis }\end{array}$ \\
\hline & ' & dúra $^{a}$ & Ananas \\
\hline & ` & dù̀a $^{a}$ & Cocos \\
\hline & $\sim$ & dữa & no meaning \\
\hline & $>$ & dửa & no meaning \\
\hline & . & dụa & to lean \\
\hline
\end{tabular}




\section{Nguyen - Insertions and Deletions: Evolution in the Assemblage of Vietnamese Food Plants}

\author{
Vietnamese vernacular botanical nomenclature
}

Vietnamese vernacular botanical nomenclature may be generalized to glosses based on: (1) large taxa defined by plant form or structure utilized (Atran 1990) (Appendix A); (2) generic ranks; and (3) specific "species" or "varieties" (Berlin 1992) that may be labeled as binomials. Examples of plant names based on form or part utilized include nấm (mushroom), rau (leafy vegetable), and trái (fruit). Examples of generic names include dưa (Cucumis), chuối (Musa), and cải (Brassica). Examples of specific names include dưa chuột (Cucumis sativa L.), chuối hột (Musa balbisiana Colla.), and cải ngọt (Brassica rapa susp. chinensis (L.) Hanelt). The plant form or part utilized is also a prefix that in some cases may designate the generic name. Examples include nấm mèo, for the tree-ear fungus (Auricularia sp.), and trái dưa chuột, the fruit of cucumber (C. sativa).

The prefix is important in cases where two species of different genera or even families share a generic name. An example is the generic name dứra (different from dura without a rising-tone diacritic) (see Table 2). The examples in Table 2 refer to meaning when combined with the prefix for a fruit, as in trái dúra (SV), referring to the fruit of Ananas comosos (L.) Merr. When it is combined with the prefix for leaf, as in lá dứa, it refers to the scented leaves of Pandanas amaryllifolius Roxb. used in cooking.

A single species may be referenced by different vernacular names corresponding to its use at different developmental stages or to distinguish the part utilized. This is well illustrated in the seeded banana, cây chuối hột (tree + Musa + seed). The staminate inflorescence, referred to as bắp chuối (SV) (bắp describes its oblong shape) or hoa chuối (NV) ("banana flower") and the young, green fruits, trái chuối chát, (fruit + banana + astringent taste) are used as raw vegetables. The fully developed seeded fruits, trái chuối hột, are dried and used medicinally. While the leaves, lá chuối, are valued for their use as a food wrapping, especially for cooking glutinous rice preparations.

Many plants introduced during the French colonial period were named with a Vietnamese life form or generic name followed by a Vietnamese version of the French name. Adopting and modifying foreign names of introduced plants is common in indigenous cultures (cf. McClatchey et al. 2000). To illustrate, the Vietnamese name for Daucus carota L., củ cà-rốt, is the result of combining the Vietnamese term for a root crop, bulb, or rhizome, củ, with the French carotte. Some introduced plants that are morphologically similar to traditional plants have names that reflect this morphology (e.g., măng tây, literal translation, "bamboo shoot of the French (or west)," otherwise known as Asparagus officinalis L.). The descriptor tây, meaning "west," was used to designate plants introduced by the French.

\section{Writing Vietnamese diacritical characters}

The Vietnamese diacritical characters in this manuscript were written in "Unicode." Writing diacritics was once problematic due to formatting and word processing difficulties. These problems have been overcome by the use of Unicode fonts and Vietnamese language programs. The Unicode Standard is an international character coding system designed to support the worldwide interchange, processing, and display of written texts of diverse languages (UNICODE 1991-2004). A number of Vietnamese language fonts and programs using Unicode are available and free to download from the Internet (UNIKEY 1991, VPS 19932001). Unicode characters are also available as standard symbols in Microsoft ${ }^{\circledR}$ Word and are supported by a number of applications (e.g. EndNote ${ }^{\circledR} 8$ and newer versions). I recommend using the Unicode Standard for Vietnamese fonts (inserted either from Microsoft Word's "Insert - Symbols" menu or as the Unicode option in the font program of choice). Both methods are broadly available and transferable without formatting corruption.

\section{Methods}

\section{Study period and sites}

The food plant list presented here was compiled as part of my dissertation research on food plant knowledge and practices of Vietnamese in the United States and in Vietnam. The research was conducted from January 2002 through April 2004 in Honolulu, Hawai'i, and Biên Hòa, Vietnam. The two locations are comparable based on the following: (1) Honolulu has an established population of Vietnamese people; (2) many Vietnamese immigrants in Honolulu are originally from southern Vietnam (Nguyen 1977); (3) Biên Hòa is in southern Vietnam (ca. 30 km north of Ho Chi Minh City); and (4) both locations are urban environments with food markets (i.e., open air markets selling food plants).

\section{Interviews and participant observation}

Ethnographic, structured interviews (Spradley 1979) with informed consent (Alexiades 1996) using questionnaires (Martin 1995) were conducted with Vietnamese men and women at least 18 years of age to collect data on food plant use and culinary habits. Interviewees were selected by snowball sampling (Bernard 2002) initiated with a Vietnamese immigrant woman in Honolulu and a Vietnamese woman of similar age in Vietnam. A free listing technique was used to obtain food plant species known and used by each interviewee (Martin 1995). Food plants were demarcated by three uses: (1) "vegetables" (rau cải), defined as any plant part or life-form of the plant that can be eaten and is often not sweet compared to most fruits of plants (e.g., leaves, stems, corms, and mature or immature fruits of the Cucurbitaceae and Solanaceae families), (2) "fruits" 
(trái cây), the developed ovary of a seed plant that may contain seeds, and (3) "spices and other ingredients for preparing food" (nguyên liệu gia vị), a plant or non-plant substance that is used to add aromatic, pungent, salty, or other additional seasoning to foods.

Participant observation (Spradley 1980) with informed consent was conducted with members of the Vietnamese communities in private homes and at public events to observe plants actually being used. This was to supplement plant data from the free-lists and to record those not listed in the interviews.

\section{Plant collections}

Vouchers of plants recorded in Hawai'i and Vietnam were collected in triplicate from some home gardens, but mostly from the produce markets of Chinatown, Honolulu (Hawaiii) and Biên Hòa (Vietnam) (Bye 1986b, Martin 1995). Vouchers were deposited at the herbaria of the University of Hawai'i (HAW) and the Institute for Ecology and Biological Resources (HN) in Hà Nội (Hanoi), Vietnam. Plants in home gardens represented by few individuals were collected singularly or in duplicate only. These specimens are deposited only at HAW. Some vouchers were recorded using only digital photography.

Many of the plants were cultivated species for which their identification is commonly known. Others were identified using the most comprehensive flora of Vietnam currently available (Phạm 1999, 2000, 2003). Specimen identifications have been confirmed by staff of $\mathrm{BISH}$ and $\mathrm{HN}$. Accepted scientific names and the associated authorities were checked using the Missouri Botanical Garden's (n.d.) VAST (VAScular Tropicos) nomenclatural database accessed via W3TROPICOS. Current botanical familyplacement was verified using APG II (2003) and the continuously updated electronic resource, the Angiosperm Phylogeny Website (Stevens 2001 onwards). The Vietnamese plant names recorded from the interviews were cross-checked using Pham $(1999,2000,2003)$ and if not included then checked in (Võ 2003). English and French names are those that occurred in descriptions of plants in Pham $(1999,2000,2003)$ and in Crevost and Lemarié (1917). Where these did not provide an English or French equivalent, some common names were available via the Multilingual Multiscript Plant Name Database (Porcher 1995-2020).

\section{Plant taxa analysis}

Descriptive statistics were used to identify plant taxa in each use-group (i.e., vegetables, fruits, and spices and other ingredients) that were listed most frequently for Hawai'i and Vietnam grouped interviews. The lists and taxa recorded during participant observations in Hawai'i and Vietnam were used to identify taxa substituted, inserted (added), and deleted (not used) in Hawai'i.

\section{Results}

\section{Interviews}

Interview responses were grouped by location, Vietnam or Hawai'i. Interviewee demographics were recorded (i.e., gender, age, occupation). As the main purpose of this report is to identify the assemblage of plant taxa used by Vietnamese location rather than the differences in plant knowledge potentially due to social characteristics (Zent \& Zent 2004), an analysis based on these demographics is not included in this paper and will be discussed in a separate paper. In both locations, I began to reach a point of diminishing returns (few or no new species listed) (Martin 1995) with approximately 30 interviews. In Biên Hòa there were a total of 41 ( 26 female, 15 male) interviewees. In Honolulu, there were a total of 34 ( 25 female, 9 male) interviewees. I believe the reason for there being more female than male interviewees is due to (1) my being female and Vietnamese and (2) the snowball method used to find interviews. As a middle aged Vietnamese woman, it is culturally easier and more appropriate for me to meet and talk with women. I believe my use of the snowball sampling method resulted in higher numbers of female interviewees because the person identifying another to be interviewed often identified a friend or relative of the same gender. Interviewees from Biên Hòa listed a total 143 taxa of food plants, which included 90 taxa referred to as "vegetables" or "spices" and 53 taxa as "fruits." While in Honolulu, 67 and 43 taxa were listed for the same food plant groups.

\section{Vietnamese food plant assemblage}

The Vietnamese food plants (Appendix B) represent a compilation of the plants recorded from structured and participant interviews in Honolulu, Hawai'i and Biên Hòa, Vietnam. The checklist has been prepared with the scientific family names and Latin binomials. In some cases, taxa and names are different from those in the floras and other recent literature on food plants of Vietnam. Plant families are presented in alphabetical order so that the checklist may be most accessible to a variety of users. Fungi appear at the end of the list. Within families, genera and species are presented in alphabetical order, followed by Vietnamese names, in different dialects where applicable, and if available, in English and French. The French names are provided to facilitate research and use of the extensive French literature concerning Vietnamese economic plants. Also listed for each species is the plant part or life form reported as being utilized by informants.

\section{Plant taxa analysis}

Plant taxa lists from Hawai'i and Vietnam were used to order the frequency of taxa demarcated by the three uses: 


\section{Nguyen - Insertions and Deletions: Evolution in the Assemblage of Vietnamese Food Plants}

(1) "vegetables" (rau cải) (Table 3), (2) "fruits" (trái cây) (Table 4), and (3) "spices and other ingredients for preparing food" (nguyên liệu gia vị) (Table 5). The vegetables and fruits tables display the top $30 \%$ of the most frequently listed plants and are discussed in the next section. The spices table includes only the order of frequency due to missing data.

Taxa substituted, inserted (added), and deleted (not used) in Hawai'i are identified using a case studies approach. The purpose of this method is to allow for a detailed culturally informative discussion of a few notable examples and their traditional use in Vietnam compared to contemporary use or in Hawai'i.

\section{Discussion}

\section{Site bias}

Due to the locations of the study sites, Hawai'i and southern Vietnam, the checklist produced may be representative of plants most salient to Vietnamese of southern Vietnam origin and living in a subtropical U.S. environment with a large East and Southeast Asian population. If this study was carried out in northern Vietnam or a northern U.S. city including different demographics, the checklist produced may include different species representative of those different climatic areas and cultural make-up.

Table 3. Most frequently listed vegetables in interviews from Biên Hòa, Vietnam and Honolulu, Hawai'i. (Approximately top $30 \%$ )

\begin{tabular}{|l|c|c|}
\hline \multicolumn{3}{|c|}{ Vegetables } \\
\hline \multirow{2}{*}{ Species } & \multicolumn{2}{|c|}{$\%$} \\
\cline { 2 - 3 } & $\begin{array}{l}\text { Biên Hòa, } \\
\text { Vietnam }\end{array}$ & $\begin{array}{l}\text { Honolulu, } \\
\text { Hawai'i }\end{array}$ \\
\hline $\begin{array}{l}\text { Brassica oleracea } \\
\text { var. capitata }\end{array}$ & 39 & 50 \\
\hline $\begin{array}{l}\text { Brassica rapa } \\
\text { subsp. chinensis }\end{array}$ & 37 & 40 \\
\hline Daucus carota & 37 & 33 \\
\hline Ipomoea aquatica & 63 & 70 \\
\hline Lactuca sativa & 54 & 47 \\
\hline Lycopersicon esculentum & 32 & \\
\hline Mentha aquatica & - & 30 \\
\hline Ocimum basilicum & - & 43 \\
\hline $\begin{array}{l}\text { Raphanus sativus } \\
\text { Longipinnatus Group }\end{array}$ & - & 30 \\
\hline Rorippa nasturtium-aquaticum & 29 & - \\
\hline Solanum tuberosum & 29 & - \\
\hline
\end{tabular}

\section{Plant taxa descriptions}

The list of Vietnamese food plants includes over 200 taxa. More taxa were added to the list or assemblage of food plants from recordings of plants observed to be used during participant observation interviews. The majority of species represent the Brassicaceae, Cucurbitaceae, Fabaceae, and Poaceae families. Species in Rutaceae and Musaceae are used most frequently for their sweet fruits. Fungi and algae are used infrequently. They were never listed in structured interviews but were observed being used during participant interviews. The fungi observed are included in the checklist. Due to the infrequency of algae use, I did not collect algae and only mention here their Vietnamese life-form term, rong.

The most frequently listed vegetables (Table 3 ) include $I p$ omoea aquatica (L.) Lam., in both Biên Hòa and Honolulu, Lactuca sativa L., second most frequent in Biên Hòa and third most frequent in Honolulu, and Brassica oleracea var. capitata L. (cabbage), third most frequent in Biên Hòa and second most frequent in Honolulu. Ipomoea aquatica is a traditional vegetable eaten throughout Vietnam. It's saliency in the Vietnamese culture is illustrated through proverbs associated with the vegetable. That it is also highly salient in Hawai'i may be an artifact of the location. Ipomoea aquatica is an important and popular food plant for other Asian groups in Hawai'i as well. It was noted as one of the early introductions by Asian immigrants to Hawai'i long before the Vietnamese came (Chung \& Ripperton 1929). Lactuca sativa and $B$. oleracea are common food plants that are in both locations. Other vegetables that were frequently listed in both locations include Brassica rapa subsp. chinensis (L.) Hanelt and Daucus carota.

Vietnamese in Honolulu more often list aromatic herbs (e.g., Ocimum basilicum, Mentha aquatica) as vegetables than respondents in Biên Hòa. This raises questions about the understandings and demarcations of food categories by respondents in the two locations. Indeed, the English term "vegetable" and the closest Vietnamese translation, rau cải, are not equivalent in their inclusion of food plants. "Vegetable" is often understood as, and was defined in this study as any plant part or life-form of the plant that can be eaten and is often not sweet compared to most fruits of plants (e.g., leaves, stems, corms, and mature or immature fruits of the Cucurbitaceae and Solanaceae families). In comparison, rau cải is not as comprehensive. Though, generally understood as "vegetables," rau cải more specifically refers to leafy and stem vegetables. People may not consider other plant forms. For example, corms are generally referred to as củ, or củ cải, referring to the swollen roots of plants also eaten as leafy vegetables. While aromatic herbs were included in the most salient vegetables for Vietnamese in Honolulu, the same was not true for those in Vietnam. This category, rau tho'm, meaning "aromatic leafy vegetables" includes herbaceous plants such as cilantro (Coriandrum sativum L.) and those in the mint 
family (Lamiaceae) including mints (Mentha spp.) and basils (Ocimum basilicum L.). Rau thom refers to those plants usually eaten raw as a garnish or included in the common table salad, rau sống (raw or uncooked vegetables that may also include raw non-leafy foods, particularly cucumbers [Cucumis sativus L.]). Even with these difficulties, most interviewees seemed to understand that I was interested in the broad definition of rau cải and included a range of "vegetables" in their listing.

Responses to listing fruits (Table 4) or trái cây came much easier for the interviewees. Pomelo (Citrus maxima (Burm. ex Rumph.) Merr.), durian (Durio zibethinus Rumph. ex Murray), and a common orange (Citrus sinensis (L.) Osbeck) are among the top three fruits named in Biên Hòa In Honolulu, the common orange is listed most frequently, followed by apples (Malus sp.) and then mangoes (Mangifera indica L.). Citrus. maxima was also frequently listed in Honolulu but at a lower percentage than in Biên Hòa. Other frequently listed fruits shared between the two locations include Musa sp., Vitis sp., and Carica papaya L. Similar to the responses in Biên Hòa, $D$. zibethinus and $C$. reticulata are highly salient to those respondents in Honolulu, although they appear just below the 30\% frequency of listing. As with the vegetables listed, the fruits results are also probably due to site bias. This is particularly so for fruits such as mangoes and pomelos that are common

Table 4. Most frequently listed fruits in interviews from Biên Hòa, Vietnam and Honolulu, Hawai'i. (Approximately top $30 \%$ )

\begin{tabular}{|l|c|c|}
\hline \multicolumn{2}{|c|}{ Fruit } & \multicolumn{2}{c|}{$\%$} \\
\cline { 2 - 3 } Species & $\begin{array}{l}\text { Biên Hòa, } \\
\text { Vietnam }\end{array}$ & $\begin{array}{l}\text { Honolulu, } \\
\text { Hawai'i }\end{array}$ \\
\hline Artocarpus heterophyllus & 37 & - \\
\hline Carica papaya & 34 & 47 \\
\hline Citrullus lanatus & 34 & - \\
\hline Citrus maxima & 54 & 30 \\
\hline Citrus reticulata & 46 & 27 \\
\hline Citrus sinensis & 51 & 82 \\
\hline Dimocarpus longan & 32 & \\
\hline Durio zibethinus & 51 & 27 \\
\hline Malus domestica & & 73 \\
\hline Mangifera indica & 49 & 73 \\
\hline Musa sp. & 41 & 63 \\
\hline Nephelium lappaceum & 34 & - \\
\hline Psidium guajava & 37 & - \\
\hline Pyrus sp. & 37 & - \\
\hline Spondias cytherea & 37 & - \\
\hline Vitis sp. & 41 & 33 \\
\hline
\end{tabular}

to Hawai'i but may not be as common in temperate U.S cities.

Comparing the two sites reveals that the Vietnamese in Vietnam have a greater diversity of fruits most salient or commonly used than Vietnamese in Honolulu. For the top $30 \%, 15$ species of fruits were listed in Biên Hòa compared to seven in Honolulu. Thus, the Vietnamese in Honolulu use more frequently a smaller assemblage of fruits than Vietnamese in Biên Hòa even though many of the same fruits are available in both locations.

Due to initial difficulties I faced in my data collection for spices or ingredients used to season foods, I do not compare the percentage values of responses from Hawai'i with those from Vietnam here. A preliminary review (Table 5 ) indicates the spices most commonly listed in both locations include black pepper (Piper nigrum L.), chilies (Capsicum annuum L.), garlic (Allium sativum L.) and onions (Allium cepa var. cepa) in Hawai'i or shallots (Allium cepa var. aggregatum $\mathrm{G}$. Don) in Vietnam. The first three spices are ingredients used to make nước chấm, the ubiquitous dipping sauce made with nước mắm (fish sauce). In Vietnam and Asian markets in the United States these plant ingredients, along with onions (Allium spp.) and limes [Citrus $x$ aurantiifolia (Christm.) Swingle], are usually sold side-by-side by a single vendor providing a "onestop shopping" situation (Figure 1). Thus Vietnamese in Hawai'i have maintained this assemblage of spice plants, except where onions are used more frequently in Honolulu as opposed to shallots in Vietnam. Vietnamese have reported the shallots are sweeter than the larger onions. This may be a substitution of onion species by Vietnamese in Hawai'i possibly due to the greater availability of the larger onions in U.S. markets.

Table 5. Seven most frequently listed spices in interviews from Biên Hòa, Vietnam and Honolulu, Hawai'i. Listed by order of frequency in each location (1=most frequent).

\begin{tabular}{|c|c|c|}
\hline \multicolumn{3}{|l|}{ Spices } \\
\hline \multirow[b]{2}{*}{ Species } & \multicolumn{2}{|c|}{ Order } \\
\hline & $\begin{array}{l}\text { Biên Hòa, } \\
\text { Vietnam }\end{array}$ & $\begin{array}{l}\text { Honolulu, } \\
\text { Hawai'i }\end{array}$ \\
\hline Allium cepa var. cepa & - & 4 \\
\hline Allium cepa var. aggregatum & 4 & - \\
\hline Allium fistulosum & 6 & 5 \\
\hline Allium sativum & 3 & 1 \\
\hline $\begin{array}{l}\text { Capsicum annuum var. cf. lon- } \\
\text { gum/frutescens }\end{array}$ & 2 & 3 \\
\hline Citrus $\mathrm{x}$ aurantiifolia & 5 & 6 \\
\hline Cymbopogon citratus & 7 & - \\
\hline Piper nigrum & 1 & 2 \\
\hline Zingiber officinalis & - & 7 \\
\hline
\end{tabular}


Nguyen - Insertions and Deletions: Evolution in the Assemblage of Vietnamese Food Plants

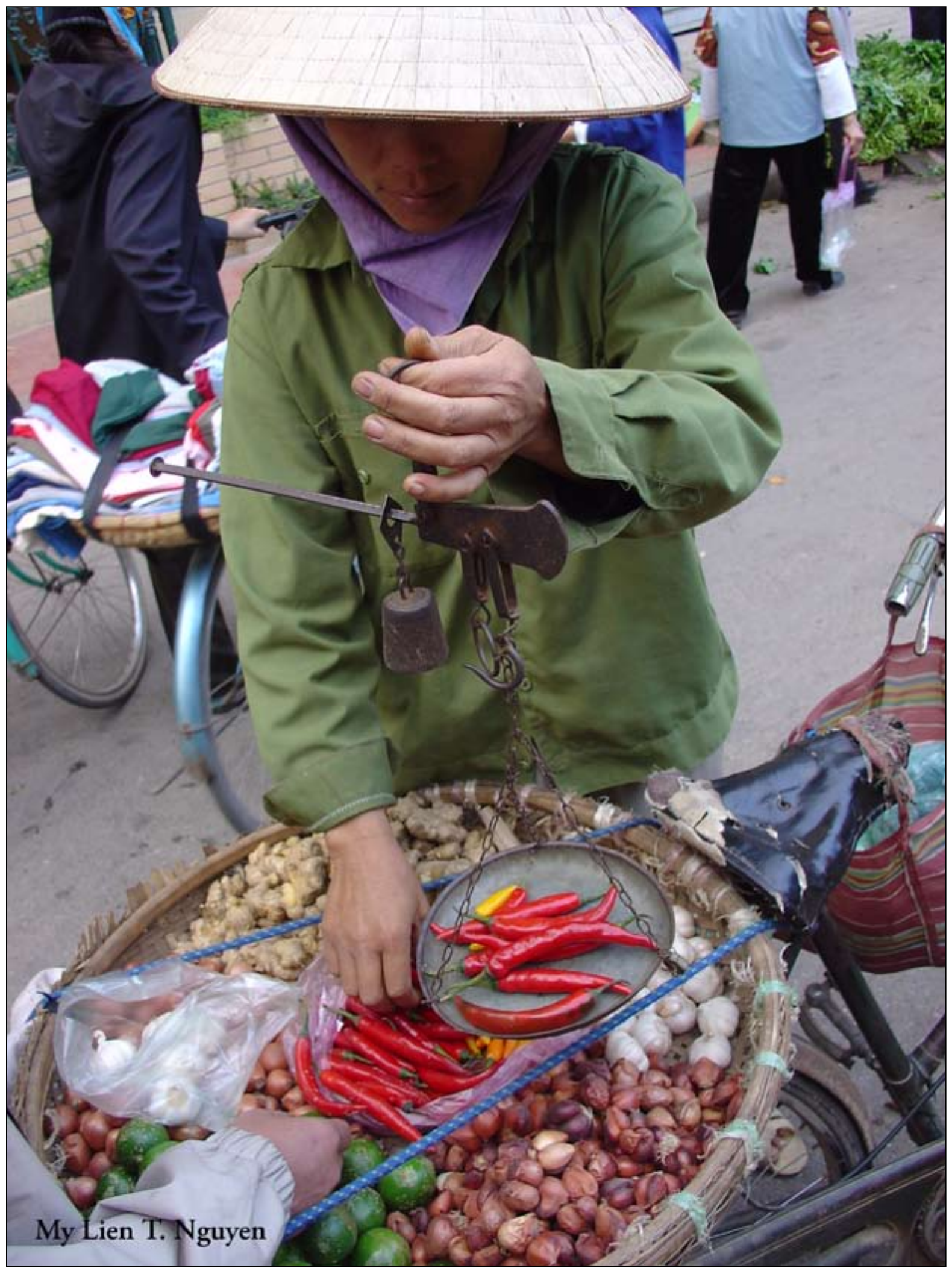

Figure 1. Spices vendor with an assemblage of plant species often used together to make the dipping sauce, nước chấm. Hanoi, Vietnam. 


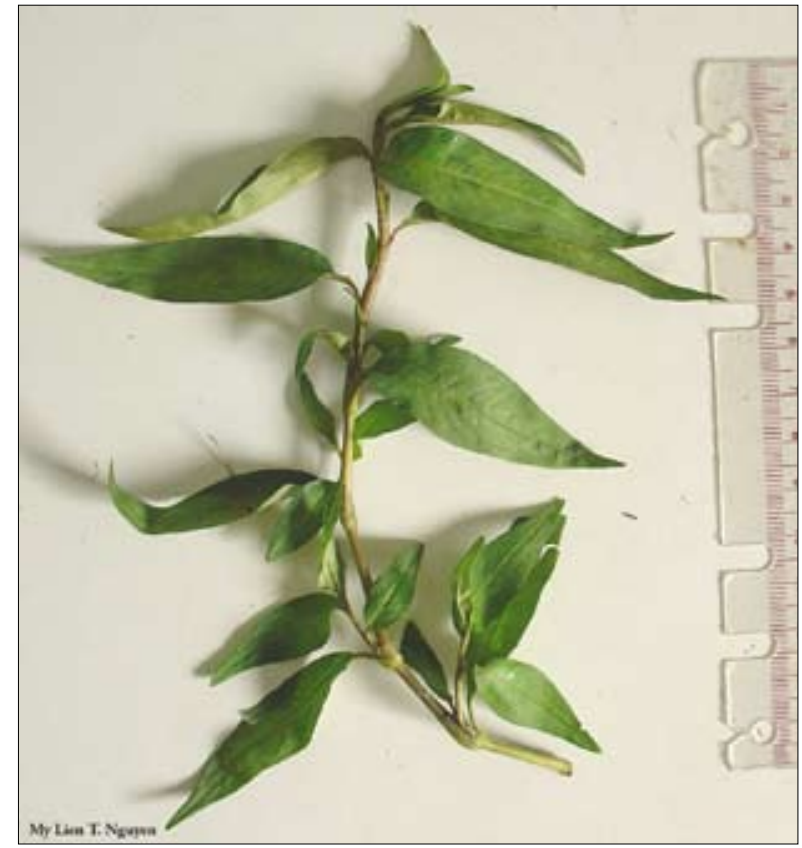

Figure 2. Persicaria odorata (Lour.) Soják (rau răm, Vietnamese mint).

\section{Substitution for aroma and taste}

Persicaria odorata (Lour.) Soják (rau răm, Vietnamese mint, indigenous to Southeast Asia) (Figure 2). It is used most notably and traditionally in salad dishes, called gỏi and as an accompaniment with the partially developed duck egg dish, hột vịt lộn (Figure 3). It is listed as a recent introduction by Vietnamese immigrants (Kuebel \& Tucker 1988) and is not included in a checklist of Asian food plants in Hawai'i (Chung \& Ripperton 1929), or other Hawai'i plant lists before 1975 (Neal 1965, St. John 1973).

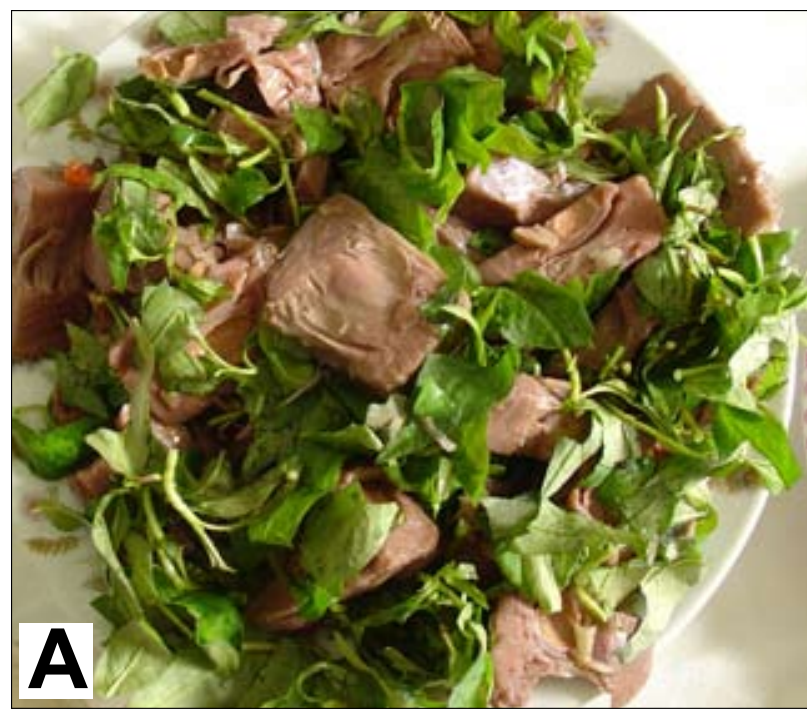

In the United States, I have not observed the partially developed duck egg dish being consumed. However, I am told that it is available in the markets in Chinatown in Honolulu and other areas with large Vietnamese communities. Regarded as a snack food, it is neither described in Vietnamese cookbooks from the United States (Miller 1968, Ngô \& Zimmerman 1986, Nhan \& Sox 2003) nor Vietnam (Nguyễn 2003, Triệu 1999, Văn 1984). For salads included in the cookbooks from the United States, the aromatic "herbs" Coriandrum sativum (indigenous to Southwest Asia) and/or Ocimum basilicum (indigenous to the oldworld tropics) is commonly listed rather than $P$. odorata. For example, green papaya salad (gỏi đu đủ) is prepared with $O$. basilicum rather than $P$. odorata. While $P$. odorata is available in the Chinatown markets in Honolulu, its use appears to be limited and I have never observed it used as an ingredient in Vietnamese restaurants in Hawai i. Only during participant observations with the Vietnamese group of Đồng Tâm Baptist Church, and during meals in Vietnam have I eaten gỏi with $P$. odorata. It is also the women of the Đồng Tâm group that stress that Vietnamese salads must have $P$. odorata in order to be genuinely and properly prepared, gỏi, with the proper taste. According to traditional Vietnamese use, $P$. odorata aids in the digestion of the partially developed duck eggs. Its antibacterial properties (Nguyễn 1993) may explain its traditional use in raw salads that may harbor harmful bacteria.

\section{Deletion and substitution used for color}

Momordica cochinchinensis (Lour.) Sprengel (gấc, indigenous to India, Japan to New Guinea). This spectacular fruit (Figure 4), is related to bitter melon (M. charantia L.). The thick, red arils of the large seeds are used to impart an orange-red color to the glutinous rice dish, xôi gấc. Xôi gấc is traditionally served for celebrations such as wed-

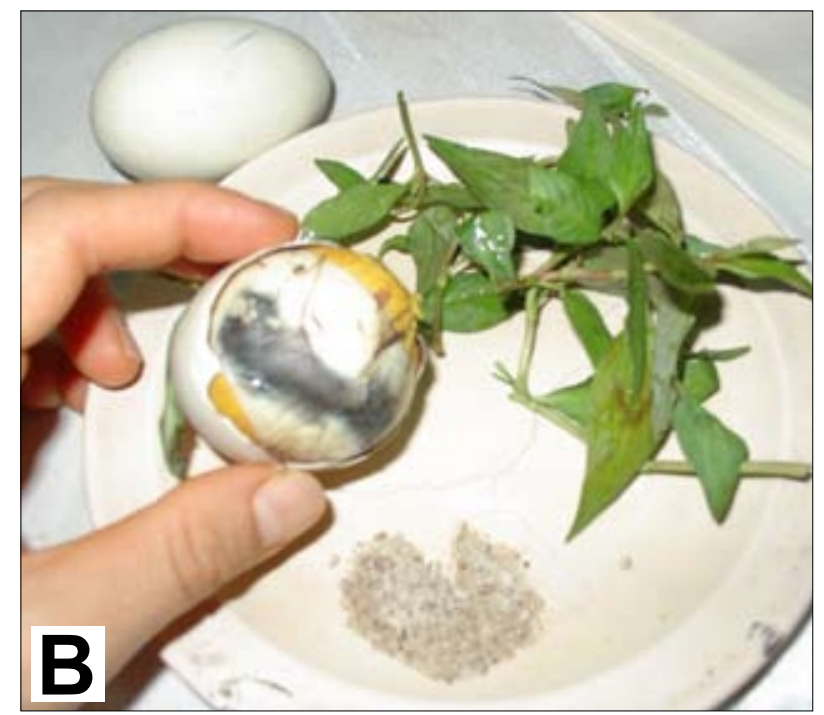

Figure 3. Persicaria odorata traditionally used for: (A) gỏi, salad dishes, (pictured is a gỏi made with Artocarpus altilis (Z.) Fosb., beadfruit); and (B) as an accompaniment in hột vịt lộn. 


\section{Nguyen - Insertions and Deletions: Evolution in the Assemblage of Vietnamese Food Plants}

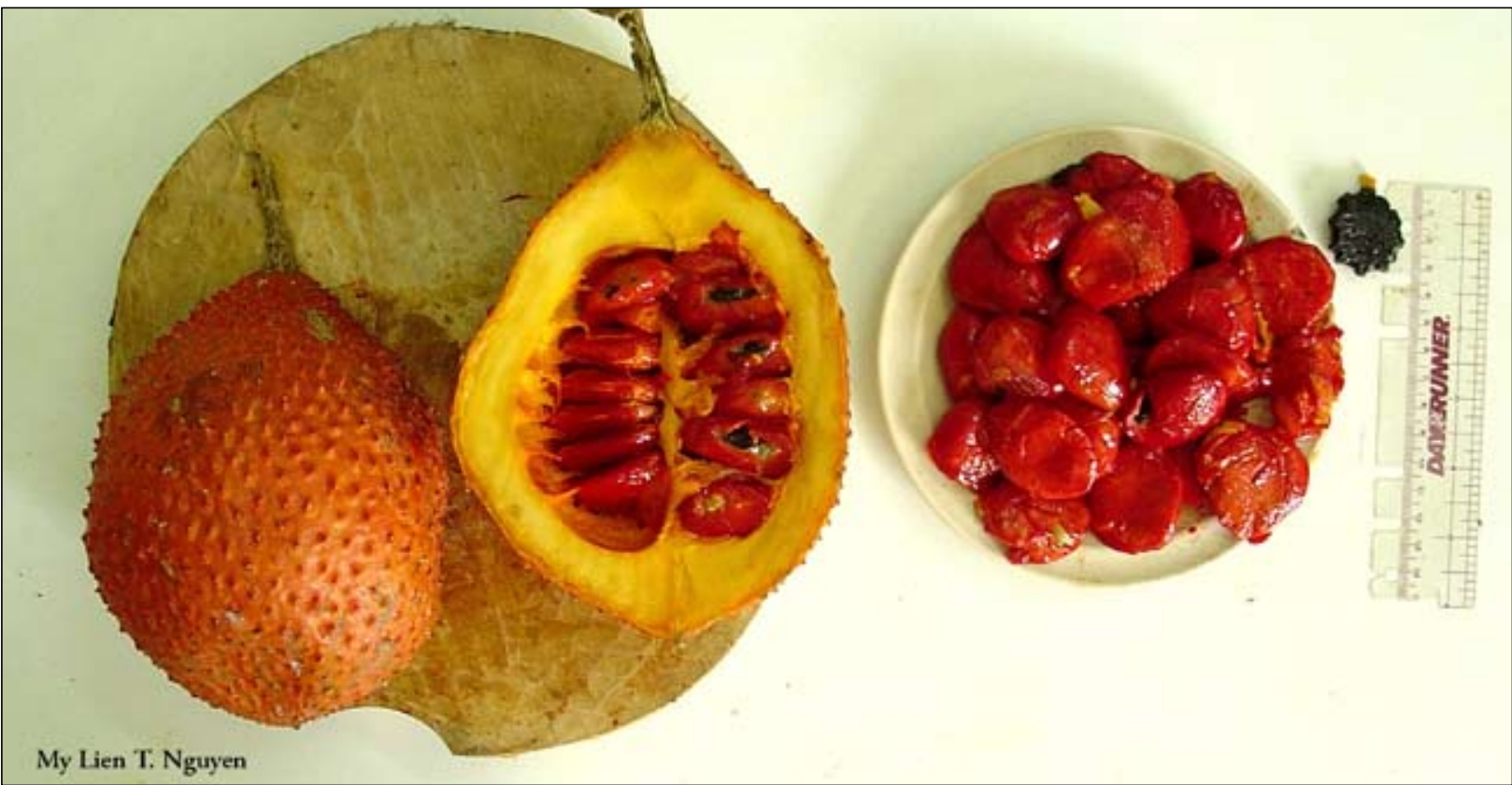

Figure 4. Momordica cochinchinensis (Lour.) Sprengel (gấc). The thick, red arils of the large black seeds are used to impart a red coloring to food.

dings, đầy tháng (the celebration of exactly one month old of a baby), and Tết (Lunar New Year). The aril covered seeds are first soaked in rice liquor. The arils are then removed from the hard seeds and mixed with uncooked glutinous rice that has been soaked in water and the mixture is steamed. Coconut milk is added to sweeten this food. The black hard seeds are not eaten as they are removed prior to or during the mixing stage. A number of seeds may be left in the mixture or are reserved to be used as decoration on top of the cooked xôi gấc (Figure $5 \mathrm{~A}$ ). This

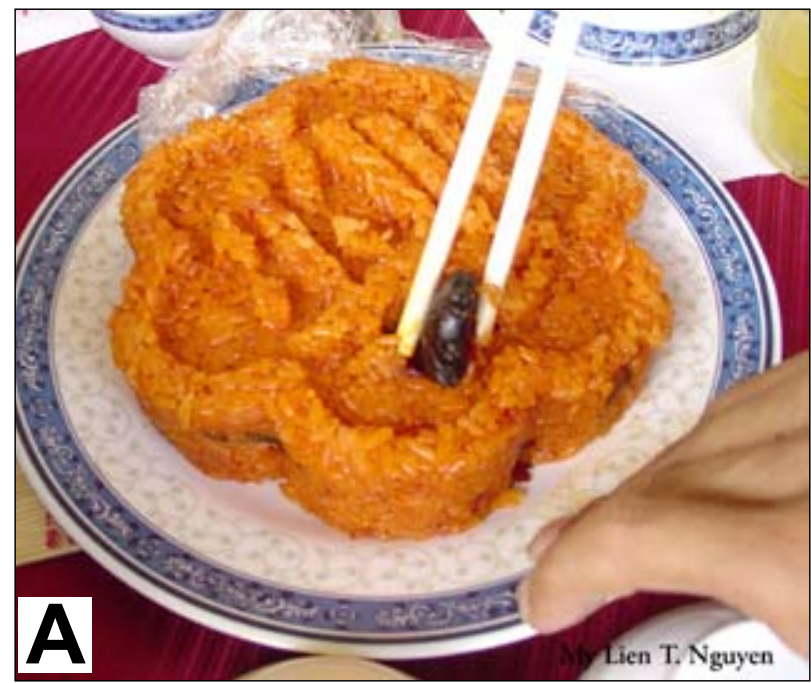

is done as evidence that $M$. cochinchinensis was indeed used to impart the coloring versus an artificial food coloring. In Hawai'i, at every Vietnamese celebration where a pink to red colored glutinous rice dish was available, I have been told it is "xôi gấc" and upon asking, I am told "[artificial] color is added" to make it red. The food coloring imparts a light red to pink hue rather than the orangered produced when using the arils of $M$. cochinchinensis (Figure 5B).

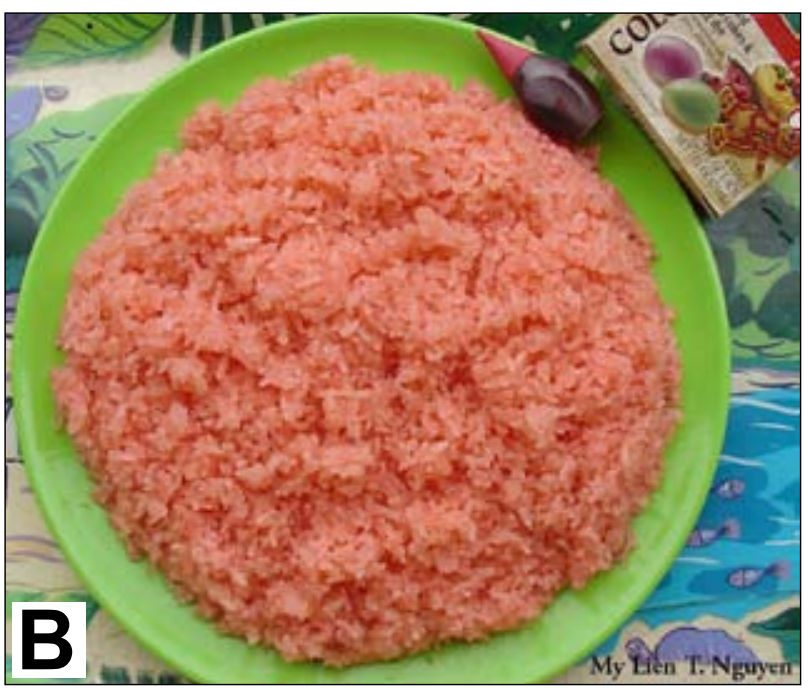

Figure 5. A) Xôi gấc served at a wedding in Vietnam. A Momordica cochinchinensis seed left in the glutinous rice mixture as proof of $M$. cochinchinensis use is being removed just before eating the food. B) Artificially colored "xôi gấc" repared with red food coloring (also shown in the figure) that produced the pink color. This dish was prepared for a Vietnamese celebration in Hawai'i. 


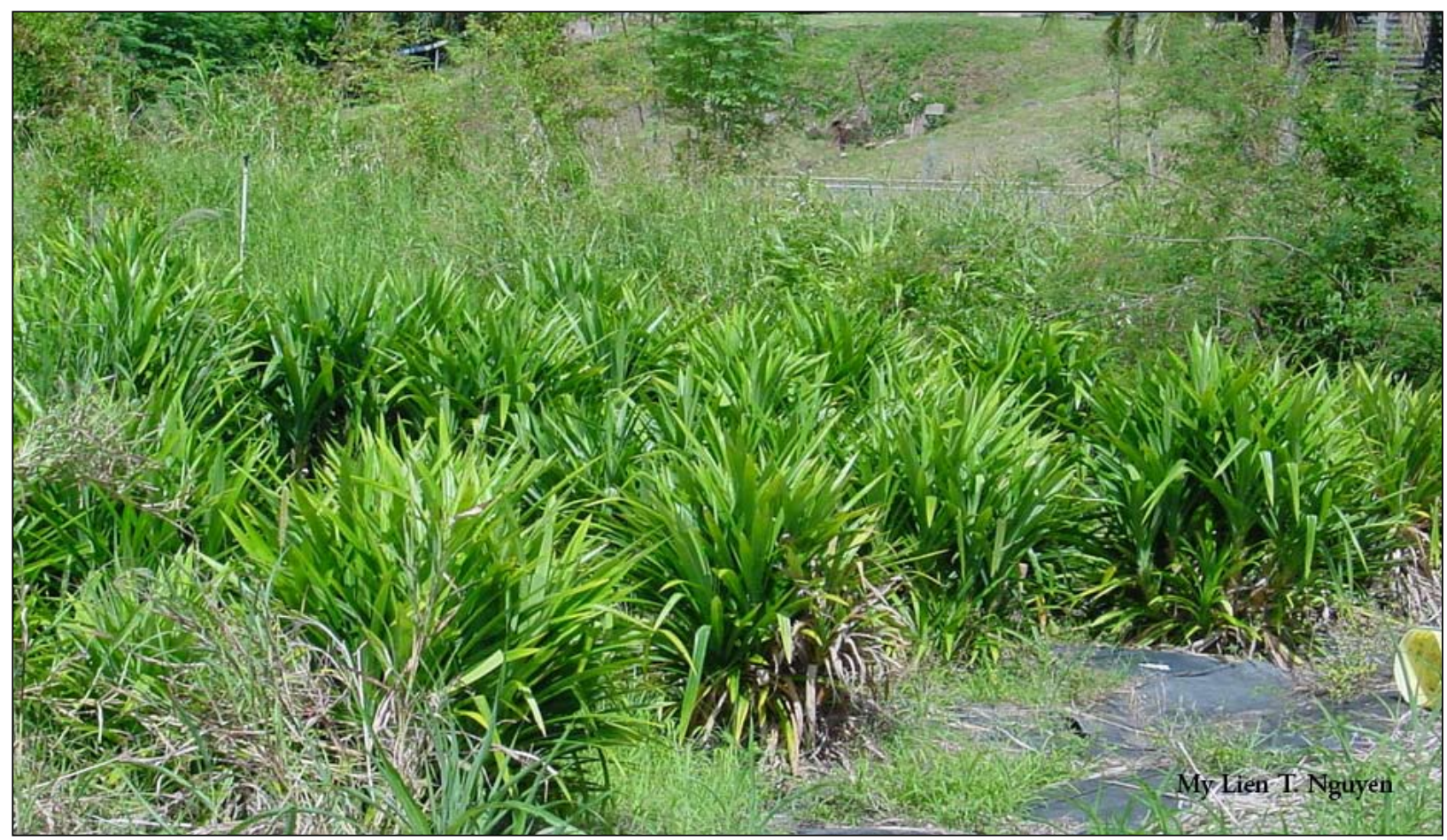

Figure 6. Pandanus amaryllifolius Roxb. (lá dứa, scented pandanus) cultivated on a Vietnamese farm in Hawai'i (plants in foreground).

While the genuine use $M$. cochinchinensis for the red of xôi gấc is important in Vietnam, its deletion in Hawai'i due to unavailability and subsequent substitution with food coloring does not appear culturally important for Hawai' $i$ based Vietnamese. In February 2005, I attended a celebration of the first full year of a baby where xôi gấc was prepared using powered $M$. cochinchinensis. The powered preparation of the $M$. cochinchinensis arils has recently become available in Vietnam and was brought back to Hawai'i by a Vietnamese woman. The powder gave the glutinous rice the deep orange-red color similar to what I have observed when the fresh arils are used. This powder is not available in Hawai'i and may become another product soon to be imported for Vietnamese immigrants.

Pandanus amaryllifolius Roxb. (lá dứa, scented pandanus, indigenous to the old world tropics, possibly first found in the Moluccas). Pandanus amaryllifolius leaves are used to perfume and to impart a green color to foods. For example, both scent and coloring properties are used to make a sweet food called, chè sôi nước, which consists of green colored spheres filled with sweetened mung bean paste. The green spheres are made with glutinous rice flour traditionally colored using water boiled with $P$. amaryllifolius. In Hawai'i, chè sôi nước is often made with green food coloring even though $P$. amaryllifolius is available (Figure 6). As with $M$. cochinchinensis, the substitution of $P$. amaryllifolius is explained to me without much empathy for traditionalism. For these two examples in Hawai' $i$, the convenience of the artificial food coloring outweighs the traditionalism of the plant use. The substitution of coloring for $M$. cochinchinensis is compounded by its unavailability in Hawai'i.

\section{Substitutions, insertions and deletions for texture}

Colocasia gigantea (Blume) Hook. f. (bạc hà, often referred by "taro stem," indigenous to Indomalasia to Australia) (Figure 7). Colocasia gigantea is valued for the spongy aerenchyma and crunchy texture of its petiole (Nguyen 2005). The petiole has no flavor of its own, but absorbs the broth of the soup it is specifically cooked in, canh chua cá lóc (sweet and sour snakehead mullet fish soup). The ingredients used to make canh chua cá lóc provide its characteristic balance of sourness, sweetness, and spiciness. These combinations are important characteristics of Vietnamese food (Đinh 1990a; Pham 2001; Trieu 1998). Less discussed is the necessity of certain plants to provide texture, as is the function of $C$. gigantea in this soup.

Vendors in Biên Hòa identified plant taxa used as substitutes for C. gigantea in canh chua (Table 6). Like C. gigantea, these plants have little or no flavor and absorb the flavor of the soup. Species A through D have aerenchyma, and thus have the texture quality coveted for $C$. gigantea (Figure 8). The plants listed for Honolulu are those I have observed in use. Apium graveolens var. dulce (Miller) Pers. is listed as an insertion in Honolulu because I did not observe it used or available in southern Vietnam. The 

Vietnamese Food Plants

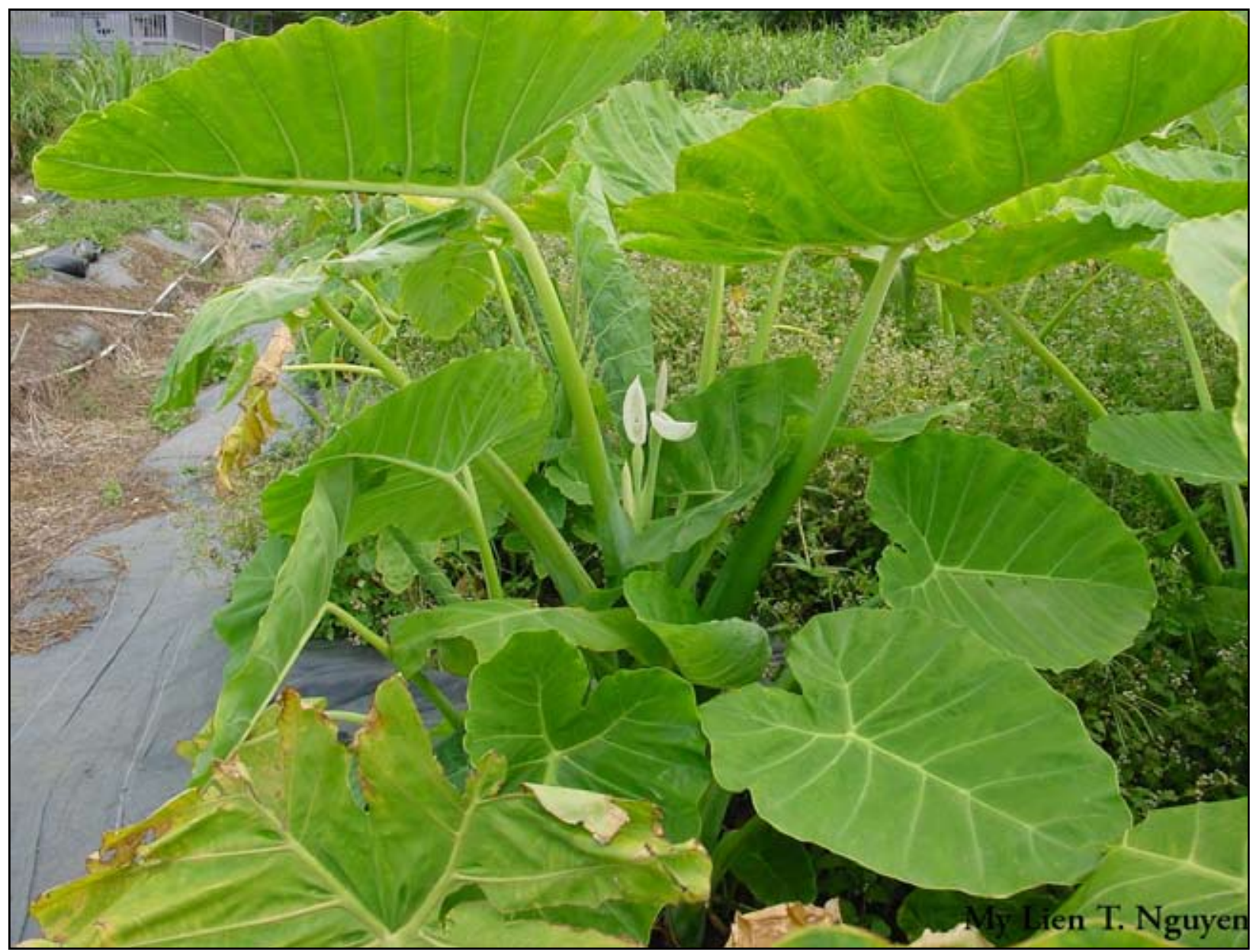

Figure 7. Colocasia gigantea (Blume) Hook. f. (bạc hà) cultivated in Hawai'i.

Table 6. Plant taxa substitutions for Colocasia gigantea, deletions and insertions for making canh chua.

\begin{tabular}{|c|c|c|}
\hline Standard & Biên Hòaa substitutions & Honolulu insertions \\
\hline \multirow{2}{*}{$\begin{array}{l}\text { Colocasia gigantea (Blume) } \\
\text { Hook.f. }\end{array}$} & A) Limnocharis flava (L.) Buchenau & 1) Apium graveolens var. dulce (Miller) DC \\
\hline & flowering shoots of "keo neo" & petiole \\
\hline \multirow[t]{12}{*}{ petiole used } & B) Nelumbo nucifera Gaertner & 2) bamboo shoots \\
\hline & shoots of "sacred lotus" & canned \\
\hline & C) Nymphaea pubescens Willd. & \\
\hline & flowering shoots of "night lotus" & \\
\hline & D) Neptunia prostrata (Lam.) Baillon & \\
\hline & whole plants, spongy stems & \\
\hline & $\begin{array}{l}\text { E) bamboo shoots from Mekong Delta } \\
\text { region: }\end{array}$ & \\
\hline & pickled & \\
\hline & F) Sesbania grandiflora (L.) Pers. & \\
\hline & blossoms & \\
\hline & G) Sesbania sesban (L.) Merr. & \\
\hline & blossoms & \\
\hline
\end{tabular}




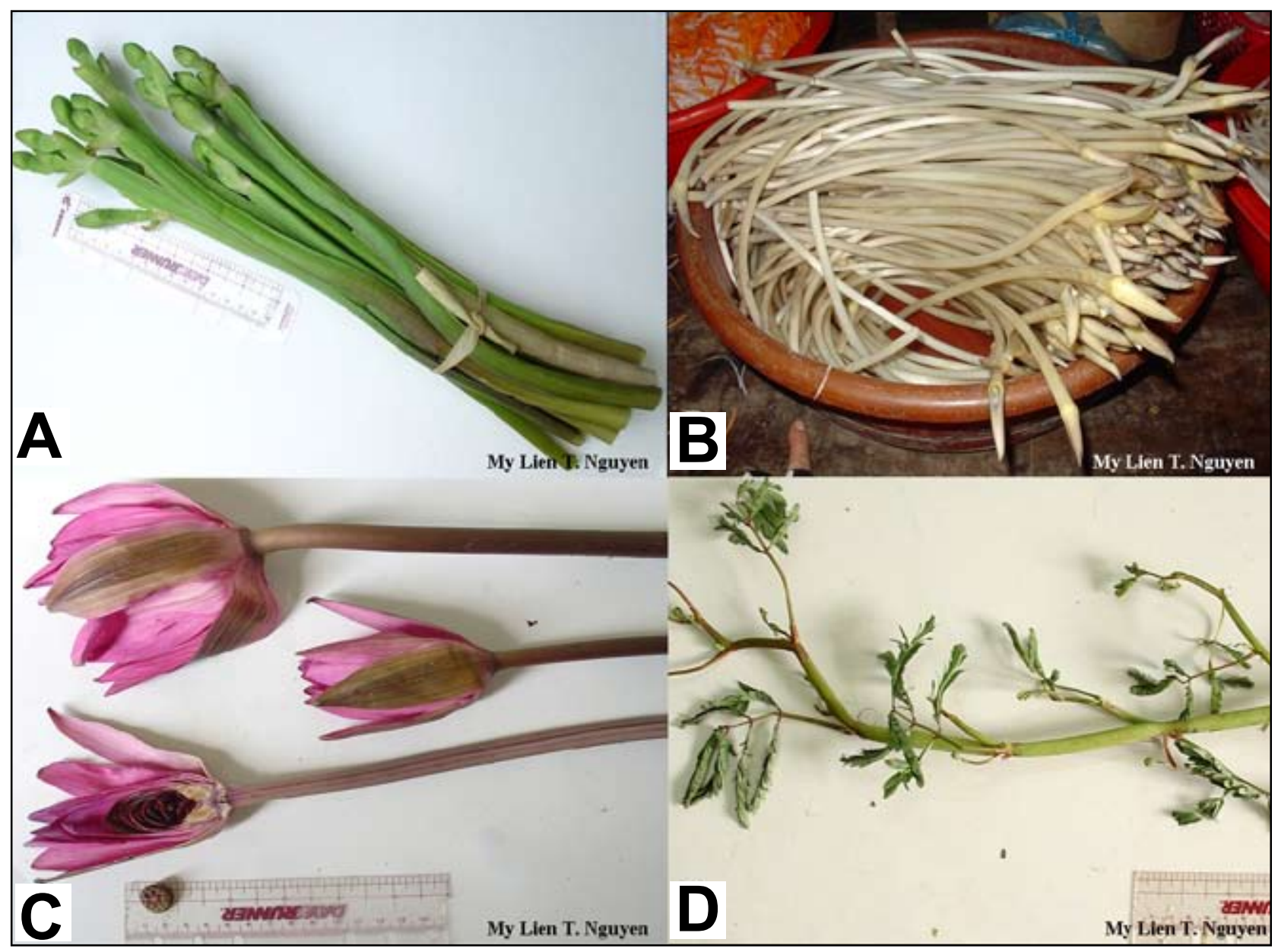

Figure 8. Texture substitutes for C. gigantea with aerenchyma: A) Limnocharis flava (L.) Buchenau, B) Nelumbo nucifera Gaertner., C) Nymphaea pubescens Willd., D) Neptunia prostrata (Lam.) Baill.

bamboo listed for Honolulu is cooked and canned versus a pickled preparation in Biên Hòa.

The C. gigantea substitutes that occur in Biên Hòa, except bamboo shoots and Sesbania grandiflora (L.) Pers., are not available in the Honolulu's Chinatown markets, and thus are considered to be "deleted" from the Hawai' $i$ based Vietnamese food plant assemblage. Nelumbo nucifera Gaertner in the form of the "lotus roots" are available in Chinatown, but the shoots as they are used for canh chua are not available. Neptunia prostrata (Lam.) Baill. is available in Chinatown, but I have never observed its use for canh chua. It is possible that $N$. prostrata was deleted from the assemblage of canh chua plants because it was not available when the Vietnamese first began to make this food in Hawai'i, and subsequently the knowledge of its application for canh chua was forgotten by many.

Sesbania grandiflora (L.) Pers. and Sesbania sesban (L.) Merr. are ingredients characteristic to canh chua of the Mekong Delta (in Vietnamese known as miền tây). Sesbania sesban flowers are described as available only dur- ing the flood season and growing along the water ways of the Mekong Delta where people use small boats to collect them from semi-aquatic S. sesban plants. Sesbania grandiflora, grows in Hawai'i, is sold in the Chinatown markets by Filipino vendors, and is used by Filipinos as a vegetable. I have observed its use for canh chua in Hawai'i infrequently by Vietnamese originally from the Mekong Delta region.

In recent years, the improved economic situation in Vietnam and for many Vietnamese immigrants in Hawai'i, has enabled people to include in canh chua a greater variety of ingredients and include those formally more expensive [e.g., pineapple (Ananas comosus (L.) Merr.) and okra (Abelmoschus esculentus (L.) Moench)] (Mrs. Nguyễn Thị Nhơn, personal interview 2004). As a result, different species of vegetables, herbs and fish (and other meats) are now more commonly used in canh chua in Vietnam and in the United States. The plant and animal species used for canh chua have been substituted, deleted and others inserted in their place, but the characteristics of the soup remain constant: sour, sweet, spicy, and a texture - pro- 


\section{Nguyen - Insertions and Deletions: Evolution in the Assemblage of Vietnamese Food Plants}

vided by the aquatic associated plants with aerenchyma, bamboo, or celery.

\section{Conclusions}

This paper provides an explanation of Vietnamese diacritics and their importance to meaning and application in Vietnamese vernacular plant names. It is hoped that the compilation of Vietnamese food plants will be useful to those working in Vietnamese economic botany or ethnobotany as a reference of the current scientific nomenclature and taxonomic groupings, the fully scribed Vietnamese names, and the English and French equivalents. As the interest in Vietnamese ethnobotany grows, it is important to be accurate and unambiguous in our research and reports. Equally important, that a greater understanding of the food practices and culture can be learned and preserved through the active use of the Vietnamese language by those that are interested, Vietnamese or otherwise.

The list of Vietnamese food plants also serves to fill a gap in the literature regarding food plants used by Vietnamese immigrants. With the collection of many of the plants in this study from Hawai'i's Chinatown markets, the data also serves as a preliminary checklist of plants available in Asian markets in the United States. This working list will evolve as additional names are added to include other plant life forms (e.g. algae) and uses (e.g. medicinal), and to accommodate the dynamic nature of botanical nomenclature.

An analysis of taxa used and that are salient to Vietnamese in Hawai'i compared with southern Vietnam reflects an evolution of the assemblage of food plants demonstrated by substitutions, insertions, and deletions of plant taxa. Replications are also evident as the Vietnamese in Hawai'i have access to many similar plant taxa as those in Vietnam. This is likely due to the location: with a subtropical climate where similar food plants can grow, and demographically, where taxa are available due to the food plants demands of the large Asian population.

Some notable substitutions, deletions, and insertions of plant taxa demonstrate that the Vietnamese in Hawai' $i$ have continued to make foods that are culturally important even in the absence of particular plant taxa. This shows that the importance of some foods is not in the species that are required, but rather the qualities of the plant (e.g., crunchy, spongy aerenchyma of Colocasia gigantea). The adaptation facilitates the food preparation or replication, maintaining Vietnamese culinary traditions.

\section{Acknowledgements}

I thank the people of the Vietnamese communities in Hawai' $i$ and in Vietnam that have facilitated my research and learning about Vietnamese culture, in particular: my aunt in Vietnam, Nguyễn Thị Gai, and in Hawai'i, Mai Thị Hụê. Operational support in Vietnam was provided by Dr. Jack Regalado of the Missouri Botanical Garden (U.S.A.) and Dr. Nguyễn Tiến Hiệp of the Institute for Ecology and Biological Resources at the National Center for Science and Technology (Hanoi, Vietnam) in collaboration with the Vietnam Botanical Conservation Program. I thank Dr. Will McClatchey for providing a helpful review of the paper.

\section{Literature Cited}

Airriess, C.A. \& D.L. Clawson. 1994. Vietnamese Market Gardens in New Orleans. Geography Review 84:16-31.

APG II. 2003. An update of the Angiosperm Phylogeny Group classification for the orders and families of flowering plants: APG II. Botanical Journal of the Linnean Society 141:399-436.

Alexiades, M.N. 1996. Selected Guidelines for Ethnobotanical Research: A field manual. New York Botanical Garden Press, Bronx, New York.

Atran, S. 1990. Cognitive Foundations of Natural History: Towards an anthropology of science. Cambridge University Press and Editions de la Maison des sciences de l'homme, Cambridge and Paris.

Berlin, B. 1992. Ethnobiological Classification: Principles of categorization of the plants and animals in traditional societies. Princeton University Press, Princeton.

Bernard, H.R. 2002. Research Methods in Anthropology: Qualitative and quantitative methods. AltaMira Press, Walnut Creek, CA.

Bye, R.A. 1986. Voucher Specimens in Ethnobiological Studies and Publications. Journal of Ethnobiology 6:1-8.

Chung, H.L. \& J.C. Ripperton. 1929. Utilization and Composition of Oriental Vegetables in Hawaii. Bulletin No. 60. Hawaii Agricultural Experiment Station, Honolulu.

Cotton, C.M. 1996. Ethnobotany Principles and Applications. John Wiley and Sons, Chichester, England.

Crevost, C. \& C. Lemarié. 1917. Catalogue des Produits de I'Indochine. Tome 1er. Produits Alimentaires et Plantes Fourragères. Gouvernement général de l'Indochine, Hanoi.

Crevost, C., C. Lemarié \& A. Pételot. 1917-1941. Catalogue des Produits de I'Indochine. (6 Tomes). Gouvernement général de l'Indochine, Hanoi. 
Đinh, H.T. 1981. Ethnobotanique Vietnamienne: état des questions, researches at perspectives. Thèse de Doct. de 3ème siècle. Université Paris VII, Paris.

Hodel, U., M. Gessler, H.C. Hoang, V.T. Vo, T.V.H. Nguyen, T.X. Nguyen \& T.B. Tran. 1999. In situ Conservation of Plant Genetic Resources in Home Gardens of Southern Vietnam. International Plant Genetic Resources Institute, Rome

Ireson, C.J. \& W.R. Ireson. 1996. Cultivating the Forest: Gender and the Decline of Wild Resources among the Tay of Northern Vietnam. East-West Center, Honolulu.

Kuebel, K.R. \& A.O. Tucker. 1988. Vietnamese culinary herbs in the United States. Economic Botany 43:413419.

Mabberley, D.J. 1997. The Plant-Book: A portable dictionary of vascular plants. Cambridge University Press, Cambridge.

Martin, G. 1995. Ethnobotany: A methods manual. Chapman and Hall, London.

McClatchey, W., R. Thaman \& S. Vodonaivalu. 2000. A preliminary checklist of the flora of Rotuma with Rotuman names. Pacific Science 54:345-363.

Missouri Botanical Garden. n.d. "w3TROPICOS". Missouri Botanical Garden's VAST (VAScular Tropicos) nomenclatural database (rev. 1.5). www.tropicos.org/.

Nguyen, C. 1977. Research Paper on the Resettlement of Vietnamese Refugees in the State of Hawaii. Vietnamese \& Indochinese Volunteer Assistance, Inc., Honolulu.

Nguyen, M.T. 2003. Comparison of Food Plant Knowledge Between Urban Vietnamese Living in Vietnam and in Hawai'i. Economic Botany 57:472-480.

Nguyen, M.T. 2004. Some like it hot...and sour. The ethnobiological evolution of "Canh Chua Cá Lóc" in Vietnamese migrations. Paper presented at the 9th International Congress of Ethnobiology. University of Kent, Canterbury, UK. 13-17 June 2004.

Nguyen, M.T. 2005. Bạc hà (Colocasia gigantea (Blume) Hook. f.), in the culinary history of Vietnamese-Americans. Economic Botany 59:185-190.

Nguyen, N.H.T. 2000. Taro diversity and use in Vietnam. Pp. 12-17 in Proceedings of the Symposium of Ethnobotanical and Genetic Study of Taro in China: Approaches for the Conservation and Use of Taro Genetic Resources. edited by D. Zhu, P.B. Eyzaguirre, M. Zhou, L. Sears \& G. Liu. Laiyang Agricultural College, Laiyang,
Shangdong, China. International Plant Genetic Resources Institute, Rome.

Ogle, B.M., H.T. Tuyet, H.N. Duyet \& N.N. Xuan Dung. 2003. Food, Feed or Medicine: The Multiple Functions of Edible Wild Plants in Vietnam. Economic Botany 57:103117.

Owens, R. 2003. Vietnamese Homegardens of Lincoln, Nebraska: A Measurement of Cultural Continuity. Master's Thesis, unpublished (Anthropology). University of Nebraska, Lincoln, Nebraska.

Phạm, H.H. 1999. Cây-cỏ Việt-Nam.- Quyển I: Từ khuyết-thực-vật, Lõa-tử đến họ Đậu (An Illustrated Flora of Vietnam - Volume I: From Pteridophyta, Gymnospermae to Papilionoideae). Nhà Xuất Bản Trẻ, Thành phố Hồ Chí Minh.

Phạm, H.H. 2000. Cây-cỏ Việt-Nam.- Quyển III: Từ Smilacaceae đến Orchidaceae (An Illustrated Flora of Vietnam - Volume III: From Smilacaceae to Orchidaceae). Nhà Xuất Bản Trẻ, Thành phố Hồ Chí Minh.

Phạm, H.H. 2003. Cây-cỏ Việt-Nam.- Quyển II: Từ Elaeagnaceae đến Scrophulariaceae (An Illustrated Flora of Vietnam - Volume II: From Elaeagnaceae to Scrophulariaceae). Nhà Xuất Bản Trẻ, Thành phố Hồ Chí Minh.

Porcher M.H. et al. 1995 - 2020. Multilingual Multiscript Plant Name Database (M.M.P.N.D) - A Work in Progress. School of Agriculture and Food Systems. Faculty of Land \& Food Resources. The University of Melbourne. Australia. www.plantnames.unimelb.edu.au/Sorting/List_bot. html.

Porterfield Jr., W.M. 1951. The Principal Chinese Vegetable Foods and Food Plants of Chinatown Markets. Economic Botany 5:3-37.

SIL International. 2004. Vietnamese: a language of Viet Nam. SIL (Summer Institute of Linguistics) International, www.ethnologue.com/show_language.asp.

Simon, P.J. \& I. Simon-Barouh. 1972. De quelques plantes du Viêt-Nam cultivées en France. Pp. 347-355 in Langues et Techniques, Nature et Société. edited by J.M.C. Thomas \& L. Bernot. Klincksieck, Paris.

Spradley, J.P. 1979. The Ethnographic Interview. Holt, Rinehart, and Winston, New York.

Spradley, J.P. 1980. Participant Observation. Holt, Rinehart, and Winston, New York. 


\section{Nguyen - Insertions and Deletions: Evolution in the Assemblage of Vietnamese Food Plants}

Staples, G.W. \& M.S. Kristiansen. 1999. Ethnic Culinary Herbs: A guide to identification and cultivation in Hawai'i. University of Hawai'i Press, Honolulu.

Stevens, P.F. 2001 onwards. Angiosperm Phylogeny Website. Version 7, May 2006 [and more or less continuously updated since]. www.mobot.org/MOBOT/research/ APweb/. Last updated 9/24/06.

Tanaka, N. 2004. The utilization of edible Canna plants in southeastern Asia and southern China. Economic Botany 58:112-114.

Unicode, Inc. 1991-2004. What is Unicode? Unicode, Inc., www.unicode.org/standard/WhatlsUnicode.html.

UniKey. 1991. UniKey: Vietnamese Keyboard for Windows. Free Software Foundation, Inc., Boston, Massachusettes. unikey.sourceforge.net/.

Võ, V.C. 2003. Từ điẻn Thực Vàt Thông Dụng, Tập 1. (Dictionary of Commonly Used Plants, Vol. 1). Nhà Xuất Bản Khoa Học và Kỹ Thuật, Thành phố Hồ Chí Minh.

VPS. 1993-2001. Vietnamese Professional Society. Vietnamese Professionals Society, Carmichael, California. www.vps.org.

Walujo, E.B. 1985. Quelques aspects ethnobotaniques des plantes alimentaires vendues chez les commercants asiatiques à Paris. En insistant plus specialement sur celles qui sont souvent utilises par les Vietnamiens. Diplome d'Etudes Approfondès (Mémoire de Diplome d'Etudes Approfondès de Biologie végétal tropicale). Université Pierre et Marie Curie - Paris VI, Paris. 
Appendix A. Vietnamese terms for plant form and structure utilized.

\begin{tabular}{l|l} 
Vietnamese terms & English Explanations \\
\hline bông (SV), hoa (NV) & flower \\
\hline cải & cabbage groups; often Brassicaceae generic \\
\hline cây & $\begin{array}{l}\text { generic for "a plant" or tree; often used as a generic for food plants with erect vegetative } \\
\text { parts }\end{array}$ \\
\hline cộng & petiole or stem \\
\hline củ & bulb, root, tuber, or rhizome \\
\hline đậu & bean; often Fabaceae generic \\
\hline hột (SV), hạt (NV) & seed, grain \\
\hline lá & leaf \\
\hline nấm & fungus \\
\hline ngó & shoot of aquatic plant \\
\hline rau & "vegetable" or vegetative, sterile, often leafy food plant \\
\hline rong & algae \\
\hline trái (SV), quả (NV) & fruit \\
\hline
\end{tabular}

aOnly those discussed in this manuscript.

ㅁ include in the checklist the form "rau t" as an abbreviation for rau thom, referring to plants with aromatic (thom) vegetative parts used as condiments. 

Vietnamese Food Plants

Appendix B. Vietnamese Food Plants with Vietnamese, English, and French Names.

\begin{tabular}{|c|c|c|c|c|}
\hline TAXON $^{a}$ & Form $^{\text {b }}$ & Vietnamese $^{c}$ & English $^{d}$ & French \\
\hline \multicolumn{5}{|l|}{ ALISMATACEAE } \\
\hline Limnocharis flava (L.) Buchenau & rau & kèo nèo & $?$ & $?$ \\
\hline \multicolumn{5}{|l|}{ ALLIACEAE } \\
\hline \multirow[t]{2}{*}{ Allium cepa var. aggregatum G.Don } & củ & hành ta & shallot & echalotte \\
\hline & bông & bông hành & onion flower & oignon fleurit \\
\hline Allium cepa var. cepa L. & củ & hành tây & onion (bulbs) & oignon \\
\hline Allium chinense G. Don. & củ & củ kiệu & Chinese onion & oignon chinoise \\
\hline Allium fistulosum $\mathrm{L}$. & rau t & 'hành lá' & $\begin{array}{l}\text { green onion, } \\
\text { spring onion }\end{array}$ & ciboule \\
\hline Allium porrum L. & cây & tỏi tây & leek & poireau \\
\hline Allium sativum $\mathrm{L}$. & củ & tỏi & garlic & ail \\
\hline \multirow[t]{2}{*}{ Allium tuberosum Rottler ex. Sprengl } & rau $t$ & 'hẹ' & Chinese chives & ail odorant \\
\hline & bông & bông hẹ & $\begin{array}{l}\text { Chinese chives } \\
\text { flowers }\end{array}$ & $?$ \\
\hline \multicolumn{5}{|l|}{ AMARANTHACEAE } \\
\hline Amaranthus tricolor L. 'Red Stripe Leaf' & rau & rau dền & Chinese amaranth & $\begin{array}{l}\text { amarante } \\
\text { comestible }\end{array}$ \\
\hline Amaranthus tricolor L. var. splendens hort. & rau & rau dền lua & red amaranth & \begin{tabular}{|l} 
brède de \\
Madagascar
\end{tabular} \\
\hline Beta vulgaris L. subsp. vulgaris & củ & $\begin{array}{l}\text { dền, dền } \\
\text { tím Đà Lạt }\end{array}$ & beet & betterave \\
\hline \multirow[t]{2}{*}{ Spinacia oleracea L. } & \multirow[t]{2}{*}{ cải } & bó xôi (SV) & \multirow[t]{2}{*}{ spinach } & \multirow[t]{2}{*}{ épinard } \\
\hline & & $\begin{array}{l}\text { 'rau dềnh } \\
\text { mỹ' (HI) }\end{array}$ & & \\
\hline \multicolumn{5}{|l|}{ ANACARDIACEAE } \\
\hline Anacardium occidentale $\mathrm{L}$. & hột & điều & cashew nut & $\begin{array}{l}\text { noix de caju; } \\
\text { anacarde }\end{array}$ \\
\hline Mangifera indica L. & trái & xoài & mango & manguier \\
\hline Spondias cytherea Sonn. & trái & cóc, vì (HI) & hog plum & pomme cythère \\
\hline \multicolumn{5}{|l|}{ ANNONACEAE } \\
\hline Annona muricata L. & trái & mãng cầu xiêm & soursop & corossol \\
\hline Annona squamosa L. & trái & mãng cầu ta & $\begin{array}{l}\text { custard apple, } \\
\text { sweet sop }\end{array}$ & pomme-cannell \\
\hline
\end{tabular}




\begin{tabular}{|c|c|c|c|c|}
\hline TAXONa $^{a}$ & Form ${ }^{b}$ & Vietnamese $^{c}$ & English $^{d}$ & French \\
\hline \multicolumn{5}{|l|}{ APIACEAE } \\
\hline Anethum graveolens $\mathrm{L}$. & lá & thì là & dill leaves, fennel & fenouil bâtard \\
\hline Apium graveolens L. var. dulce (Miller) DC & rau & cần tâu, cần tây & celery & céleri \\
\hline Centella asiatica (L.) Urb. & rau & rau má & pennywort & - \\
\hline \multirow[t]{2}{*}{ Coriandrum sativum $\mathrm{L}}$. & \multirow[t]{2}{*}{ rau t } & 'ngò' (SV) & \multirow[t]{2}{*}{ cilantro } & \multirow[t]{2}{*}{ coriandre } \\
\hline & & rau mùi (NV) & & \\
\hline Daucus carota L. & củ & cà rốt & carrot & carotte \\
\hline \multirow[t]{2}{*}{ Eryngium foetidum $\mathrm{L}$. } & \multirow[t]{2}{*}{ rau t } & 'ngò gai' (SV) & \multirow[t]{2}{*}{ thorny coriander } & \multirow[t]{2}{*}{ panicaut fétide } \\
\hline & & 'mùi tau' (NV) & & \\
\hline Oenanthe javanica DC & rau & $\begin{array}{l}\text { cần nước/ta, } \\
\text { ngò tàu }\end{array}$ & Chinese celery & persil séri \\
\hline \multicolumn{5}{|l|}{ APOCYNACEAE } \\
\hline \multirow[t]{2}{*}{ Aganonerion polymorphum Pierre ex Spire } & \multirow[t]{2}{*}{ rau } & rau dang (SV) & \multirow[t]{2}{*}{$?$} & \multirow[t]{2}{*}{$?$} \\
\hline & & rau vang (NV) & & \\
\hline \multicolumn{5}{|l|}{ ARACEAE } \\
\hline \multirow[t]{2}{*}{ Colocasia esculenta (L.) Schott } & \multirow[t]{2}{*}{ củ } & khoai môn (SV) & \multirow[t]{2}{*}{ taro } & \multirow[t]{2}{*}{ taro } \\
\hline & & khoai sọ (NV) & & \\
\hline $\begin{array}{l}\text { Colocasia esculenta (L.) Schott } \\
\text { 'Bun Long' }\end{array}$ & củ & $\begin{array}{l}\text { khoai môn } \\
\text { tầu/cao }\end{array}$ & Chinese taro & taro \\
\hline \multirow[t]{2}{*}{ Colocasia gigantea (Blume) Hook. f. } & \multirow[t]{2}{*}{ cộng } & bạc hà (SV) & \multirow{2}{*}{$\begin{array}{l}\text { taro petiole (of } \\
\text { Giant elephant }\end{array}$} & \multirow[t]{2}{*}{ kane thuon } \\
\hline & & dọc mùng (NV) & & \\
\hline \multicolumn{5}{|l|}{ ARECACEAE } \\
\hline Areca catechu L. & trái & cau & betel nut & aréquier \\
\hline Arenga pinnata (Wurmb.) Merr. & cây & $\begin{array}{l}\text { đoát, bụng } \\
\text { báng }\end{array}$ & sugar palm & palmier à sucre \\
\hline Borassus flabellifer $\mathrm{L}$. & cây & thốt lốt & $\begin{array}{l}\text { palmyra palm } \\
\text { (sugar) }\end{array}$ & palmier à sucre \\
\hline Cocos nucifera L. & trái & dùra & coconut & cocotier \\
\hline \multicolumn{5}{|l|}{ ASPARAGACEAE } \\
\hline Asparagus officinalis L. & rau & măng tây & asparagas & apserge \\
\hline \multicolumn{5}{|l|}{ ASPHODELACEAE } \\
\hline Aloe vera (L.) Burm. f. & cây & $\begin{array}{l}\text { cây đam, } \\
\text { nha đam }\end{array}$ & aloe vera & aloès \\
\hline \multicolumn{5}{|l|}{ ASTERACEAE } \\
\hline \multirow[t]{2}{*}{ Chrysanthemum coronarium $\mathrm{L}$. } & \multirow[t]{2}{*}{ rau } & tần ô (SV) & chrysanthemum & chrysanthemum \\
\hline & & cải cúc (NV) & greens & des Jardin \\
\hline Cynara scolymus L. & bông & a-ti-sô & artichoke & artichaut \\
\hline Lactuca sativa L. cv. & rau & $\begin{array}{l}\text { xà lách } \\
\text { búp (SV) }\end{array}$ & lettuce (round cv.) & laitue \\
\hline & & diếp (NV) & & \\
\hline Lactuca sativa L. cv. & & xà lách gài (SV) & lettuce (long cv.) & \\
\hline
\end{tabular}


Vietnamese Food Plants

\begin{tabular}{|c|c|c|c|c|}
\hline TAXONa $^{a}$ & Form $^{b}$ & Vietnamese $^{c}$ & English $^{d}$ & French \\
\hline \multicolumn{5}{|l|}{ BASELLACEAE } \\
\hline Basella rubra L. & rau & mồng tơi & Malabar spinach & $\begin{array}{l}\text { epinard de } \\
\text { Malabar }\end{array}$ \\
\hline \multicolumn{5}{|l|}{ BIGNONIACEAE } \\
\hline Cresentia cujete L. & trái & đầo tiên & calabash tree & calebrassier \\
\hline \multicolumn{5}{|l|}{ BIXACEAE } \\
\hline Bixa orellana L. & hột & điều đở/nhuộm & anatto seeds & rocouyer \\
\hline \multicolumn{5}{|l|}{ BRASSICACEAE } \\
\hline \multirow[t]{3}{*}{ Brassica juncea (L.) Czern. } & \multirow[t]{2}{*}{ cải } & cải sạy (SV) & \multirow[t]{2}{*}{ mustard cabbage } & \multirow{2}{*}{$\begin{array}{l}\text { moutarde } \\
\text { indienne }\end{array}$} \\
\hline & & 'rau cải' (NV) & & \\
\hline & cải & cải bẹ xanh & $\begin{array}{l}\text { mustard cabbage } \\
\text { (small leaf) }\end{array}$ & \begin{tabular}{|l|} 
moutarde \\
indienne \\
\end{tabular} \\
\hline \multicolumn{5}{|l|}{ Brassica oleracea L. } \\
\hline var. acephala DC. & cải & cải rỗ & collard & chou cavalier \\
\hline \multirow[t]{2}{*}{ var. botrytis L. } & \multirow[t]{2}{*}{ cải } & $\begin{array}{l}\text { 'bông cải', } \\
\text { súp lo' }\end{array}$ & cauliflower & chou-fleur \\
\hline & & ‘bông cải xanh' & broccoli & $\begin{array}{l}\text { chou-fleur } \\
\text { d'hiver }\end{array}$ \\
\hline var. capitata L. & cải & 'bắp cải' & cabbage & chou cabus \\
\hline var. chinensis (L.) Prair & cải & cải dung/nhúng & Chinese kale & $\begin{array}{l}\text { broccet de } \\
\text { Chine }\end{array}$ \\
\hline var. gongylodes L. & cải & su-hào & kohlrabi & chou-rave \\
\hline \multirow[t]{3}{*}{$\begin{array}{l}\text { Brassica rapa L. subsp. } \\
\text { chinensis (L.) Hanelt }\end{array}$} & \multirow[t]{3}{*}{ cải } & cải bẹ-trắng & \begin{tabular}{|l} 
bok choy \\
(narrow petiole)
\end{tabular} & $\begin{array}{l}\text { chou chinois } \\
\text { blanc }\end{array}$ \\
\hline & & cải thìa & $\begin{array}{l}\text { bok choy } \\
\text { (broad petiole) }\end{array}$ & chou chinois \\
\hline & & cải ngọt & $\begin{array}{l}\text { choy sum, yellow } \\
\text { flowering }\end{array}$ & chou chinois \\
\hline subsp. pekinensis (Lour.) Hanelt & & $\begin{array}{l}\text { cải bắc thảol } \\
\text { bắp dài }\end{array}$ & $\begin{array}{l}\text { Chinese cabbage, } \\
\text { (long white) } \\
\text { won bak }\end{array}$ & $\begin{array}{l}\text { chou (blanc) } \\
\text { de Pékin }\end{array}$ \\
\hline Raphanus sativus Bailey cv. Longipinnatus & củ & củ cải trắng & daikon & radis-navet \\
\hline \multirow[t]{2}{*}{ Rorippa nasturtium-aquaticum (L.) Hayek } & \multirow[t]{2}{*}{ cải } & $\begin{array}{l}\text { cải xaong/ } \\
\text { soong }\end{array}$ & \multirow[t]{2}{*}{ watercress } & \multirow[t]{2}{*}{$\begin{array}{l}\text { cresson de } \\
\text { fontaine }\end{array}$} \\
\hline & & xà lách son & & \\
\hline \multicolumn{5}{|l|}{ BROMELIACEAE } \\
\hline \multirow[t]{2}{*}{ Ananas comosus (L.) Merr. } & \multirow[t]{2}{*}{ trái } & $\begin{array}{l}\text { khóm, thơm } \\
\text { (SV) }\end{array}$ & \multirow[t]{2}{*}{ pineapple } & \multirow[t]{2}{*}{ ananas } \\
\hline & & dứa (NV) & & \\
\hline \multicolumn{5}{|l|}{ CACTACEAE } \\
\hline Hylocereus undatus (Haw.) Britton \& Rose & trái & $\begin{array}{l}\text { than long, } \\
\text { tường liên }\end{array}$ & dragon fruit & oeil de dragon \\
\hline \multicolumn{5}{|l|}{ CARICACEAE } \\
\hline Carica papaya L. & trái & $\begin{array}{l}\text { đu đủ, đu } \\
\text { đủ xanh }\end{array}$ & $\begin{array}{l}\text { papaya, } \\
\text { green papaya }\end{array}$ & papayer \\
\hline
\end{tabular}




\begin{tabular}{|c|c|c|c|c|}
\hline TAXON $^{a}$ & Form $^{\mathrm{b}}$ & Vietnamese $^{c}$ & English $^{d}$ & French \\
\hline \multicolumn{5}{|l|}{ CLUSIACEAE } \\
\hline Calophyllum sp. & trái & mù-u & $\begin{array}{l}\text { Alexander } \\
\text { laurel wood }\end{array}$ & \begin{tabular}{|l|} 
laurier \\
d'Alexandrie
\end{tabular} \\
\hline Garcinia mangostana L. & trái & măng cụt & mangosteen & mangoustanier \\
\hline \multicolumn{5}{|l|}{ CONVOLVULACEAE } \\
\hline \multirow[t]{2}{*}{ Ipomoea batatas (L.) Lamk. } & củ & khoai lang & sweet potato & \multirow[t]{2}{*}{ patate douce } \\
\hline & rau & rau lang/lang đỏ & \begin{tabular}{|l|} 
sweet potato \\
leaves/red leaves
\end{tabular} & \\
\hline \multirow[t]{2}{*}{ Ipomoea aquatica Forrsk cv. } & \multirow[t]{2}{*}{ rau } & rau muống (hột) & $\begin{array}{l}\text { water spinach } \\
\text { (seed, land) }\end{array}$ & \multirow[t]{2}{*}{ liseron d'eau } \\
\hline & & \begin{tabular}{|l|}
$\begin{array}{l}\text { rau muống } \\
\text { (ruong) }\end{array}$ \\
\end{tabular} & \begin{tabular}{|l}
$\begin{array}{l}\text { water spinach } \\
\text { (paddy) }\end{array}$ \\
\end{tabular} & \\
\hline \multicolumn{5}{|l|}{ CUCURBITACEAE } \\
\hline Benincasa hispida (Thunb.) Cogn. & trái & bí đao, bí & $\begin{array}{l}\text { wax gourd, } \\
\text { Chinese winter } \\
\text { melon }\end{array}$ & courge cireuse \\
\hline \multirow[t]{2}{*}{ Citrullus lanatus (Thunb.) Matsum \& Nakai } & \multirow[t]{2}{*}{ trái } & $\begin{array}{l}\text { dưa hấu, } \\
\text { dưa đỏ }\end{array}$ & watermelon & \multirow[t]{2}{*}{ pastèque } \\
\hline & & $\begin{array}{l}\text { dưa hương/ } \\
\text { hấu non }\end{array}$ & $\begin{array}{l}\text { watermelon } \\
\text { (very young) }\end{array}$ & \\
\hline Coccinia grandis (L.) Voigt. & lá & bình bát, bát & ivy gourd & $\begin{array}{l}\text { gourde écarlate } \\
\text { de l'Inde }\end{array}$ \\
\hline Cucumis melo L. var. cantalupo Ser. & trái & dưa gang tây & canteloupe & cantaloup \\
\hline Cucumis sativus $\mathrm{L}$. & trái & dưa chuột/leo & cucumber & concumbre \\
\hline var. sativus Chinese Group & trái & dưa gang & $\begin{array}{l}\text { netted yellow } \\
\text { cucumber }\end{array}$ & $\begin{array}{l}\text { concombre } \\
\text { brodé de Chine }\end{array}$ \\
\hline \multirow[t]{2}{*}{ Cucurbita pepo L. } & trái & bí đỏ & pumpkin & courgette \\
\hline & bông & bông bí & pumpkin blossoms & courge-fleur \\
\hline var. medullosa Alef. & trái & bầu tây & zucchini & courgette \\
\hline var. moschata Duchesne ex Lam. & trái & bí rợ & Japanese pumpkin & $\begin{array}{l}\text { courge } \\
\text { musquée, } \\
\text { giraumon }\end{array}$ \\
\hline \multirow[t]{2}{*}{ Lagenaria siceraria (Mollina) Standley } & trái & bầu & bottle gourd & courge bouteille \\
\hline & lá & lá bầu & $\begin{array}{l}\text { bottle gourd } \\
\text { leaves }\end{array}$ & $\begin{array}{l}\text { feuilles de } \\
\text { courge bouteille }\end{array}$ \\
\hline Luffa acutangula (L.) Roxb. & trái & mướp khía & $\begin{array}{l}\text { ridged gourd, } \\
\text { sing-kwa }\end{array}$ & $\begin{array}{l}\text { courge } \\
\text { anguleuse } \\
\text { de Chine }\end{array}$ \\
\hline Luffa aegyptiaca Mill. & trái & mướp hương & $\begin{array}{l}\begin{array}{l}\text { sponge gourd, } \\
\text { loofah }\end{array} \\
\end{array}$ & \begin{tabular}{|l|} 
eponge \\
végétale
\end{tabular} \\
\hline \multirow[t]{2}{*}{ Momordica charantia L. } & \multirow[t]{2}{*}{ trái } & khổ qua(SV) & \multirow{2}{*}{$\begin{array}{l}\text { bitter melon, } \\
\text { balsam pear }\end{array}$} & \multirow[t]{2}{*}{ margose amère } \\
\hline & & mướp đắng(NV) & & \\
\hline $\begin{array}{l}\text { Momordica cochinchinensis } \\
\text { (Lour.) Sprengel }\end{array}$ & trái & gấc & $\begin{array}{l}\text { spiny bitter } \\
\text { cucumber }\end{array}$ & $\begin{array}{l}\text { muricie, } \\
\text { margose à } \\
\text { piquants }\end{array}$ \\
\hline Sechium edule (Jacq.) Sw. & trái & su su, chu chu & chayote & cheyotte \\
\hline
\end{tabular}


Vietnamese Food Plants

\begin{tabular}{|c|c|c|c|c|}
\hline TAXONa & Form $^{\mathrm{b}}$ & Vietnamese $^{c}$ & English $^{d}$ & French \\
\hline \multicolumn{5}{|l|}{ CUCURBITACEAE (cont.) } \\
\hline Trichosanthes cucumerina L. & trái & mướp tây & snake gourd & serpent végétal \\
\hline Zehneria indica (Lour.) Keyr. & trái & $\begin{array}{l}\text { chùm thắng/ } \\
\text { trắng }\end{array}$ & Indian zehneria & $?$ \\
\hline \multicolumn{5}{|l|}{ DIOSCOREACEAE } \\
\hline Dioscorea alata L. & củ & khoai mo/tím & $\begin{array}{l}\text { yam (purple } \\
\text { inside) }\end{array}$ & grande igname \\
\hline Dioscorea esculenta (Lour.) Burkill & củ & khoai tù̀ & yam (Chinese - ) & $\begin{array}{l}\text { igname des } \\
\text { Chine }\end{array}$ \\
\hline Dioscorea sp. & củ & khoai mọi & yam cv. & igname \\
\hline \multicolumn{5}{|l|}{ EBENACEAE } \\
\hline Diospyros kaki L.f. & trái & hồng & persimmon & kaki \\
\hline \multicolumn{5}{|l|}{ EUPHORBIACEAE } \\
\hline Manihot esculenta Crantz & củ & khoai mì & cassava & manioc \\
\hline \multicolumn{5}{|l|}{ FABACEAE } \\
\hline \multirow[t]{2}{*}{ Arachis hypogaea L. } & \multirow[t]{2}{*}{ đậu } & đậu phọng (SV) & \multirow[t]{2}{*}{ peanut } & \multirow[t]{2}{*}{ arachide } \\
\hline & & ‘đỗ lạc’ (NV) & & \\
\hline Erythrina variegata $\mathrm{L}$. & lá & vông nem & Indian coral tree & arbe immortel \\
\hline Glycine max (L.) Merr. & đậu & đậu nành & soy bean & soya \\
\hline Neptunia prostrata (Lam.) Baill. & rau & rau ngúc/ngút & neptunia & $\begin{array}{l}\text { neptunie } \\
\text { potagère }\end{array}$ \\
\hline \multirow[t]{2}{*}{ Pachyrhizus erosus (L.) Urb. } & \multirow[t]{2}{*}{ củ } & củ sắn (SV) & \multirow[t]{2}{*}{ yambean tuber } & \multirow{2}{*}{$\begin{array}{l}\text { dolique } \\
\text { bulbeuse }\end{array}$} \\
\hline & & củ đậu (NV) & & \\
\hline Phaseolus vulgaris L. & đậu & đậu ve/cô ve & French bean & haricot vert \\
\hline Pisum sativum L. & đậu & $\begin{array}{l}\text { đậu petit pois/ } \\
\text { hòa lan }\end{array}$ & pea & petit pois \\
\hline Pisum sativum L. var. macrocarpon Serr. & đậu & đậu tí bo & $\begin{array}{l}\text { snap/snow peas } \\
\text { (podded) }\end{array}$ & $\begin{array}{l}\text { pois mangetout } \\
\text { à cosse plate }\end{array}$ \\
\hline Psophocarpus tetragonolobus (L.) DC & đậu & đậu rồng & winged bean & pois carre \\
\hline \multirow{2}{*}{$\begin{array}{l}\text { Pueraria montana (Lour.) Merr. var. } \\
\text { lobata (Willd.) Maesen \& S. Almeida }\end{array}$} & \multirow[t]{2}{*}{ củ } & cát cãn (SV) & \multirow[t]{2}{*}{ kudzu } & \multirow[t]{2}{*}{ kudzu dolique } \\
\hline & & sắn dây (NV) & & \\
\hline Sesbania grandiflora (L.) Pers. & bông & bông so đũa & sesban & sesbanie \\
\hline Sesbania sesban (L.) Merr. & bông & bông điên điển & Indian sesbania & $\begin{array}{l}\text { sesbanie } \\
\text { d'Egypte }\end{array}$ \\
\hline \multirow[t]{3}{*}{ Tamarindus indica L. } & \multirow[t]{2}{*}{ trái } & me (chua) & tamarind (sour) & \multirow[t]{2}{*}{ tamarinier } \\
\hline & & me (ngọt) & tamarind (sweet) & \\
\hline & lá & lá me & $\begin{array}{l}\text { tamarind leaf } \\
\text { shoots }\end{array}$ & $\begin{array}{l}\text { feuilles de } \\
\text { tamarin } \\
\end{array}$ \\
\hline Vicia faba $\mathrm{L}$. & đậu & $\begin{array}{l}\text { đậu tâu-kêl } \\
\text { răng-ngụ̣a }\end{array}$ & broad bean & fève \\
\hline Vigna angularis (Willd.) Ohwi \& Phashi & đậu & đậu đỏ, đậu đen & $\begin{array}{l}\text { adzuki beans } \\
\text { (red, black) }\end{array}$ & $\begin{array}{l}\text { haricot adzuki } \\
\text { (pourpre, noir) }\end{array}$ \\
\hline
\end{tabular}




\begin{tabular}{|c|c|c|c|c|}
\hline TAXON $^{a}$ & Form $^{b}$ & Vietnamese $^{c}$ & English $^{\mathrm{d}}$ & French \\
\hline \multicolumn{5}{|l|}{ FABACEAE (cont.) } \\
\hline \multirow[t]{2}{*}{ Vigna radiata (L.) R. Wilczek } & đậu & đậu xanh & mung bean & \begin{tabular}{|l|} 
haricot mung \\
à grain doré
\end{tabular} \\
\hline & rau & giá & $\begin{array}{l}\text { mung bean } \\
\text { sprouts }\end{array}$ & germe de soja \\
\hline $\begin{array}{l}\text { Vigna unguiculata subsp. } \\
\text { unguiculata (L.) Walp. }\end{array}$ & đậu & đậu trắng & $\begin{array}{l}\text { cowpeas (black- } \\
\text { eyed peas) }\end{array}$ & $\begin{array}{l}\text { doliques à } \\
\text { oeil noir }\end{array}$ \\
\hline $\begin{array}{l}\text { Vigna unguiculata (L.) Walp. } \\
\text { subsp. sequipedalis (L.) Verdc. }\end{array}$ & đậu & đậu đũa & yard long beans & dolique asperge \\
\hline \multicolumn{5}{|l|}{ HEMEROCALLIDACEAE } \\
\hline \multirow[t]{2}{*}{ Hemerocallis fulva (L.) L. } & \multirow[t]{2}{*}{ bông } & kim châm (SV) & \multirow[t]{2}{*}{ lily buds } & \multirow[t]{2}{*}{ hémérocalle } \\
\hline & & 'hoa hiên' (NV) & & \\
\hline \multicolumn{5}{|l|}{ IRIACEAE } \\
\hline Eleutherine subaphylla Gagnep. & củ & $\begin{array}{l}\text { sâm đại } \\
\text { hành, tỏi đỏ }\end{array}$ & red garlic & $?$ \\
\hline \multicolumn{5}{|l|}{ LAMIACEAE } \\
\hline Elsholtzia ciliata (Thunb.) Hyl. & rau t & 'kinh giới' & Vietnamese perilla & $?$ \\
\hline Mentha aquatica $\mathrm{L}$. & rau t & 'húng lũi' & $\begin{array}{l}\text { creeping or } \\
\text { water mint }\end{array}$ & menthe aquatic \\
\hline Mentha arvensis L. & rau t & 'húng cây' & corn-mint & \begin{tabular}{|l|} 
menthe des \\
champs
\end{tabular} \\
\hline \multirow[t]{2}{*}{ Ocimum basilicum $\mathrm{L}$. } & rau t & $\begin{array}{l}\text { 'húng quế', } \\
\text { 'rau quế' }\end{array}$ & Asian/Thai basil & basilic \\
\hline & hột & hột é & $\begin{array}{l}\text { Asian/Thai } \\
\text { basil seeds }\end{array}$ & $\begin{array}{l}\text { graines de } \\
\text { basilic }\end{array}$ \\
\hline Perilla fructescens (L.) Britt. & rau $\mathrm{t}$ & 'lá tiá tô' & perilla, chiso & pérille \\
\hline Plectranthus amboinicus (Lour.) Spreng. & lá & lá cân dày & $\begin{array}{l}\text { plectranthus, } \\
\text { Cuban oregano }\end{array}$ & $\begin{array}{l}\text { plectranthus } \\
\text { aromatique }\end{array}$ \\
\hline \multicolumn{5}{|l|}{ LAURACEAE } \\
\hline Cinnamomum sp. & cây & quế đơn & cinnamon & cannelle \\
\hline \multicolumn{5}{|l|}{ LYTHRACEAE } \\
\hline Punica granatum $\mathrm{L}$. & trái & Iưu & pomegranate & grenadier \\
\hline \multicolumn{5}{|l|}{ MALPIGHIACEAE } \\
\hline Malpighia glabra L. & trái & so' ri & Barbados cherry & moureiller \\
\hline \multicolumn{5}{|l|}{ MALVACEAE } \\
\hline Abelmoschus esculentus (L.) Moench & đậu & đậu bắp & okra & gombo \\
\hline Corchorus olitorius L. & rau & rau đây/bố/đai & $\begin{array}{l}\text { Jew's mallow, } \\
\text { Tossa Jute }\end{array}$ & $\begin{array}{l}\text { corète } \\
\text { potagère jute }\end{array}$ \\
\hline Durio zibethinus Rumph. ex Murray & trái & sầu riêng & durian & durion \\
\hline Theobroma cacao L. & cây & ca-cao & cacao tree & cacaoyer \\
\hline \multicolumn{5}{|l|}{ MARANTACEAE } \\
\hline Maranta arundinaceae L. & củ & $\begin{array}{l}\text { huỳnh tinh, } \\
\text { bình tinh }\end{array}$ & $\begin{array}{l}\text { West Indies } \\
\text { arrowroot }\end{array}$ & arrow-root \\
\hline
\end{tabular}


Vietnamese Food Plants

\begin{tabular}{|c|c|c|c|c|}
\hline TAXONa & Form $^{\text {b }}$ & Vietnamese $^{c}$ & English $^{d}$ & French \\
\hline \multicolumn{5}{|l|}{ MELIACEAE } \\
\hline Lansium domesticum Corrêa & trái & bòn bon & langsati & langsep \\
\hline \multicolumn{5}{|l|}{ MENISPERMACEAE } \\
\hline Cyclea peltata (Lamk.)Hook.f. \& Thomson & lá & $\begin{array}{l}\text { sâm nam, } \\
\text { dây sâm }\end{array}$ & $?$ & $?$ \\
\hline \multicolumn{5}{|l|}{ MORACEAE } \\
\hline Artocarpus altilis (Park.) Fosb. & trái & xa kê & breadfruit & arbre-à-pain \\
\hline Artocarpus heterophyllus Lam. & trái & mít (ước, ráo) & $\begin{array}{l}\text { jackfruit (wet } \\
\text { \& dry cvs.) }\end{array}$ & jacquier \\
\hline Artocarpus integer (Thunb.) Merr. & trái & mít tố nũ & champedak & $\begin{array}{l}\text { jacquier } \\
\text { champeden }\end{array}$ \\
\hline \multicolumn{5}{|l|}{ MORINGACEAE } \\
\hline Moringa oleifera Lam. & trái & chùm-ngây & $\begin{array}{l}\text { moringa, horse- } \\
\text { radish tree }\end{array}$ & moringa ailée \\
\hline \multicolumn{5}{|l|}{ MUNTINGIACEAE } \\
\hline Muntingia calabura L. & trái & $\begin{array}{l}\text { trái trứng cá, } \\
\text { mật sâm }\end{array}$ & $\begin{array}{l}\text { calabura, } \\
\text { jamaica cherry }\end{array}$ & calabure \\
\hline \multicolumn{5}{|l|}{ MUSACEAE } \\
\hline \multicolumn{5}{|c|}{ Musa acuminata x balbisiana Colla (synonym for M. x paradisiaca L.) } \\
\hline cf. 'apple' & trái & chuối pom & apple banana & banane pomme \\
\hline \multirow[t]{2}{*}{ cf. 'cavendish' } & \multirow[t]{2}{*}{ trái } & chuối già (SV) & \multirow{2}{*}{$\begin{array}{l}\text { large (green) } \\
\text { banana }\end{array}$} & \multirow{2}{*}{$\begin{array}{l}\text { banane- } \\
\text { Cavendish }\end{array}$} \\
\hline & & chuối tiêu (NV) & & \\
\hline cf. 'ice cream' & trái & chuối sụ̣ & (angled) banana & banane cv. \\
\hline \multirow[t]{2}{*}{ 'lady finger' or 'date' } & \multirow[t]{2}{*}{ trái } & chuối cau (SV) & \multirow[t]{2}{*}{ lady finger banana } & \multirow{2}{*}{$\begin{array}{l}\text { banane-arec, } \\
\text { banane-figue }\end{array}$} \\
\hline & & chuối ngụ̣ (NV) & & \\
\hline $\mathrm{cv}$. & trái & chuối chà bột & banana cv. & banane cv. \\
\hline $\mathrm{cv}$. & trái & chuối sắp & $\begin{array}{l}\text { small, cooking } \\
\text { banana }\end{array}$ & banane cv. \\
\hline \multirow[t]{4}{*}{ Musa cf. balbisiana Colla. } & trái & chuối hột & seeded banana & \begin{tabular}{|l} 
banane \\
farineuse
\end{tabular} \\
\hline & trái & chuối chát & $\begin{array}{l}\text { stringent banan } \\
\text { (green, unripe) }\end{array}$ & $\begin{array}{l}\text { banane- } \\
\text { astringente }\end{array}$ \\
\hline & \multirow[t]{2}{*}{ bông } & ‘bắp chuối’ (SV) & \multirow{2}{*}{$\begin{array}{l}\text { banana bud / } \\
\text { inflorescence }\end{array}$} & \multirow[t]{2}{*}{ fleur de banane } \\
\hline & & 'hoa chuối' (NV) & & \\
\hline \multicolumn{5}{|l|}{ MYRTACEAE } \\
\hline Psidium guajava L. & trái & ổi & guava & goyavier \\
\hline $\begin{array}{l}\text { Syzigium aromaticum (L.) } \\
\text { Merr. \& L.M.Perry }\end{array}$ & bông & đinh hương & clove & clous de girofle \\
\hline $\begin{array}{l}\text { Syzygium samarangense } \\
\text { (Blume) Merr. \& L.M.Perry }\end{array}$ & trái & mận & water apple & $\begin{array}{l}\text { jamerose, } \\
\text { pomme de Java }\end{array}$ \\
\hline
\end{tabular}




\begin{tabular}{|c|c|c|c|c|}
\hline TAXON $^{a}$ & Form $^{b}$ & Vietnamese $^{c}$ & English $^{\mathrm{d}}$ & French \\
\hline \multicolumn{5}{|l|}{ NELUMBONACEAE } \\
\hline \multirow[t]{4}{*}{ Nelumbo nucifera Gaertn. } & củ & củ sen & lotus root & $\begin{array}{l}\text { rhizomes } \\
\text { de lotus }\end{array}$ \\
\hline & hột & hột sen & lotus seeds & graines de lotus \\
\hline & lá & lá sen & lotus leaf & feuille de lotus \\
\hline & ngó & ngó sen & lotus shoot & tige de lotus \\
\hline \multicolumn{5}{|l|}{ NYMPHAEACEAE } \\
\hline Nymphaea pubescens Willd. & bông & bông súng & night lotus & nénephar \\
\hline \multicolumn{5}{|l|}{ OXALIDACEAE } \\
\hline Averrhoa carambola L. & trái & khế & $\begin{array}{l}\text { star fruit, } \\
\text { carambola }\end{array}$ & carambolier \\
\hline Oxalis sp. & lá & me đất & sorrel & surelle \\
\hline \multicolumn{5}{|l|}{ PANDANACEAE } \\
\hline Pandanus amaryllifolius Roxb. & lá & $\begin{array}{l}\text { lá dứa, } \\
\text { dứa thơm }\end{array}$ & scented pandanus & $?$ \\
\hline \multicolumn{5}{|l|}{ PASSIFLORACEAE } \\
\hline Passiflora edulis Sims. & trái & chùm bao trứng & passion fruit & grenadille \\
\hline \multicolumn{5}{|l|}{ PEDALIACEAE } \\
\hline \multirow[t]{2}{*}{ Sesamum orientale L. } & \multirow[t]{2}{*}{ hột } & mè (SV) & \multirow[t]{2}{*}{ sesame seeds } & \multirow{2}{*}{$\begin{array}{l}\text { grains de } \\
\text { sésame }\end{array}$} \\
\hline & & vùng (NV) & & \\
\hline \multicolumn{5}{|l|}{ PHYLLANTHACEAE } \\
\hline Phyllanthus acidus (L.) Skeels & trái & chùm ruột & \begin{tabular}{|l} 
otaheite \\
gooseberry
\end{tabular} & groseille-étoile \\
\hline Sauropus androgynus (L.) Merr. & rau & bồ ngót & $\begin{array}{l}\text { star gooseberry, } \\
\text { sweet leaf }\end{array}$ & $?$ \\
\hline \multicolumn{5}{|l|}{ PIPERACEAE } \\
\hline Peperomia pellucida (L.) Kunth. & rau & càng cua & peperomia & cresson \\
\hline Piper betle L. & lá & trầu & betel leaf & bétel \\
\hline Piper lolot C.DC. & lá & lá lốt & Iolot leaf & poivre lolot \\
\hline Piper nigrum L. & hột & tiêu & pepper & poivier \\
\hline \multicolumn{5}{|l|}{ PLANTAGINACEAE } \\
\hline Plantago major L. & lá & mã đày & plantain & $\begin{array}{l}\text { plantain des } \\
\text { oiseaux }\end{array}$ \\
\hline \multicolumn{5}{|l|}{ POACEAE } \\
\hline Coix lacryma-jobi L. & hột & bô bô & Job's tears & larmes de job \\
\hline Cymbopogon citratus (DC) Stapf & cây & sả & lemon grass & citronelle \\
\hline $\begin{array}{l}\text { cf. Dendrocalamus asper (Schult. } \\
\text { \& Schult.f.) Backer ex K.Heyne }\end{array}$ & cây & $\begin{array}{l}\text { măng tre } \\
\text { manh tông }\end{array}$ & $\begin{array}{l}\text { bamboo shoots } \\
\text { of rough bamboo }\end{array}$ & $\begin{array}{l}\text { pousses de } \\
\text { bambou }\end{array}$ \\
\hline cf. Gigantochloa levis (Blanco) Merr. & cây & măng tre tầu & $\begin{array}{l}\text { bamboo shoots } \\
\text { of Smooth-shoot } \\
\text { gigantochloa }\end{array}$ & $\begin{array}{l}\text { pousses de } \\
\text { bambou }\end{array}$ \\
\hline \multirow[t]{2}{*}{ Oryza sativa L. } & cây & lúa & paddy rice & \multirow[t]{2}{*}{ riz } \\
\hline & hột & gạo & rice (dehusked) & \\
\hline
\end{tabular}


Nguyen - Insertions and Deletions: Evolution in the Assemblage of

Vietnamese Food Plants

\begin{tabular}{|c|c|c|c|c|}
\hline TAXONa & Form $^{b}$ & Vietnamese $^{c}$ & English $^{d}$ & French \\
\hline \multicolumn{5}{|l|}{ POACEAE (cont.) } \\
\hline \multirow[t]{2}{*}{ Oryza sativa L. var. glutinosa (Lour.) Körn } & cây & lúa nếp & $\begin{array}{l}\text { paddy glutinous } \\
\text { rice }\end{array}$ & \multirow[t]{2}{*}{ riz gluant } \\
\hline & hột & gạo nếp & $\begin{array}{l}\begin{array}{l}\text { glutinous rice } \\
\text { (dehusked) }\end{array} \\
\end{array}$ & \\
\hline Saccharum officinarum $\mathrm{L}$. & cây & mía & sugar cane & canne à sucre \\
\hline Triticum aestivum $\mathrm{L}$. & cây & lúa-mì & wheat & blé \\
\hline \multirow[t]{2}{*}{ Zea mays L. } & \multirow[t]{2}{*}{ trái } & bắp (SV) & \multirow[t]{2}{*}{ corn } & \multirow{2}{*}{$\begin{array}{l}\text { Mais, blé } \\
\text { d'Amérique }\end{array}$} \\
\hline & & ngô (NV) & & \\
\hline \multicolumn{5}{|l|}{ POLYGONACEAE } \\
\hline Persicaria odorata (Lour.) Soják & rau t & rau răm & Vietnamese mint & $\begin{array}{l}\text { renouée, } \\
\text { persicaire du } \\
\text { Vietnam }\end{array}$ \\
\hline \multicolumn{5}{|l|}{ ROSACEAE } \\
\hline Fragaria ananassa (Weston) Duchesne & trái & $\begin{array}{l}\text { dâu, dâu tâyl } \\
\text { Đà Lạt }\end{array}$ & strawberry & frasier \\
\hline Malus domestica Borkh. & trái & pom, táo tây & apple & pommier \\
\hline Pyrus communis L. & trái & lê & pear & poirier \\
\hline Pyrus pyrifolia (Burmf.) Nakai & trái & lê trung quốc & Asian pear & poitier de chine \\
\hline \multicolumn{5}{|l|}{ RUBIACEAE } \\
\hline Coffea sp. & hột & cà-phê & coffee & café \\
\hline Morinda citrifolia L. & trái & nhàu & Indian mulberry & motinde \\
\hline Paederia scandens (Lour.) Merr. & lá & lá mơ/thui đít & Chinese fever vine & danaide fétide \\
\hline \multicolumn{5}{|l|}{ RUTACEAE } \\
\hline Aegle marmelos (L.) Corrêa & trái & bầu nâu, mấm & Indian bael fruit & $\begin{array}{l}\text { oranger du } \\
\text { Malabar }\end{array}$ \\
\hline $\begin{array}{l}\text { Citrofortunella microcarpa } \\
\text { (Bunge) Wijnands }\end{array}$ & trái & tắc & kimquat & calamondin \\
\hline Citrus hystrix DC. & lá & lá chanh & kaffir lime (leaves) & limettier hérissé \\
\hline Citrus maxima (Burm. ex Rumph.) Merr. & trái & bưởi & pomelo & pamplemousse \\
\hline Citrus reticulata Blanco & trái & quít xiêm & $\begin{array}{l}\text { tangerine } \\
\text { (Thailand cv.) } \\
\end{array}$ & mandarinier \\
\hline Citrus sinensis (L.) Osbeck & trái & cam & sweet orange & oranger \\
\hline Citrus X nobilis Lour. & trái & cam sành & king orange & roi-de-siam \\
\hline Citrus $\mathrm{X}$ aurantiifolia (Christm.) Swingle & trái & chanh ta & lime & limettier \\
\hline Citrus X limon (L.) Burm.f. & trái & chanh tây & lemon & citron \\
\hline \multicolumn{5}{|l|}{ SAPINDACEAE } \\
\hline Dimocarpus longan Lour. & trái & $\begin{array}{l}\text { nhãn (-tiêu/ } \\
\text { dabò) }\end{array}$ & $\begin{array}{l}\text { longan 'pepper } \\
\text { seed' / 'cow skin' }\end{array}$ & longanier \\
\hline Litchi chinensis Sonn. & trái & vải & litchi & litchi \\
\hline Nephelium lappaceum L. & trái & chôm chôm & rambutan & litchi chevelu \\
\hline
\end{tabular}




\begin{tabular}{|c|c|c|c|c|}
\hline TAXON $^{a}$ & Form $^{b}$ & Vietnamese $^{c}$ & English $^{d}$ & French \\
\hline \multicolumn{5}{|l|}{ SAPOTACEAE } \\
\hline Chrysophyllum cainito L. & trái & vú sữa & star apple & cainitier \\
\hline Manilkaria zapota (L.) P. Royen & trái & xa bô chê & sapotillo & sapotillier \\
\hline Pouteria campechiana (Kunth) Baehni & trái & trái trứng gà & egg fruit, canistel & $\begin{array}{l}\text { jaune d'oeuf, } \\
\text { canistel }\end{array}$ \\
\hline \multicolumn{5}{|l|}{ SAURURACEAE } \\
\hline Houttuynia cordata Thunb. & rau $t$ & 'giấp cá' & $\begin{array}{l}\text { lizard's tail herb, } \\
\text { fish mint }\end{array}$ & houttuynie \\
\hline \multicolumn{5}{|l|}{ SCHISANDRACEAE } \\
\hline \multirow[t]{2}{*}{ Illicium verum Hook.f. } & \multirow[t]{2}{*}{ bông } & $\begin{array}{l}\text { đai hồi thật, } \\
\text { mác hồi }\end{array}$ & \multirow[t]{2}{*}{ Chinese star anise } & \multirow[t]{2}{*}{$\begin{array}{l}\text { anis étoilée anis } \\
\text { de la Chine }\end{array}$} \\
\hline & & bong phở (HI) & & \\
\hline \multicolumn{5}{|l|}{ SCROPHULARIACEAE } \\
\hline Bacopa monnieri (L.) Wettst. & rau & rau đắng & water hyssop & \begin{tabular}{|l|} 
bacopa de \\
monnier
\end{tabular} \\
\hline $\begin{array}{l}\text { Limnophila chinensis subsp. } \\
\text { aromatica (Lam.) T.Yamaz. }\end{array}$ & rau $t$ & $\begin{array}{l}\text { 'ngò om', } \\
\text { 'rau om' }\end{array}$ & rice paddy herb & $?$ \\
\hline \multicolumn{5}{|l|}{ SOLANACEAE } \\
\hline $\begin{array}{l}\text { Capsicum annuum var. } \\
\text { grossum (L.) Sendtn. }\end{array}$ & trái & ót ngọt/Đà Lạt & sweet peppers & \begin{tabular}{|l} 
poivre \\
rouge/vert
\end{tabular} \\
\hline $\begin{array}{l}\text { Capsicum annuum cf. longum Bailey } \\
\text { / cf. frutescens (L.) Kuntze }\end{array}$ & trái & ót & $\begin{array}{l}\text { chili peppers, bird } \\
\text { chili peppers }\end{array}$ & $\begin{array}{l}\text { piment, des } \\
\text { oiseax }\end{array}$ \\
\hline Lycium chinensis Miller & cây & câu khởi/ky & matrimony vine & lyciet \\
\hline Lycopersicon esculentum Miller & trái & $\begin{array}{l}\text { cà chua/tô } \\
\text { mách }\end{array}$ & tomato & tomate \\
\hline $\begin{array}{l}\text { Solanum melongena var. } \\
\text { esculentum (Dunal) Nees }\end{array}$ & trái & cà dái dê, cà tím & eggplant (purple) & aubergine \\
\hline Solanum cf. torvum Sw. / cf. undatum Jacq. & trái & cà pháo & $\begin{array}{l}\text { Thai or pea } \\
\text { eggplant }\end{array}$ & \begin{tabular}{|l} 
aubergine \\
- sauvage \\
d'Asie / pois
\end{tabular} \\
\hline Solanum tuberosum L. & củ & khoai tây/Đà lật & $\begin{array}{l}\text { white potato, } \\
\text { red potato }\end{array}$ & pomme de terre \\
\hline \multicolumn{5}{|l|}{ THEACEAE } \\
\hline \multirow[t]{2}{*}{ Camelia sinensis (L.) Kuntze } & \multirow[t]{2}{*}{ lá } & trà (xanh) (SV) & \multirow[t]{2}{*}{ tea (green) } & \multirow[t]{2}{*}{ théier } \\
\hline & & ché (NV) & & \\
\hline \multicolumn{5}{|l|}{ VITACEAE } \\
\hline Vitis sp. & trái & nho & (dessert) grapes & vigne \\
\hline \multicolumn{5}{|l|}{ ZINGIBERACEAE } \\
\hline Alpinia galanga (L.) Willd. & củ & riềng nếp & galangal (larger) & galanga (grand) \\
\hline Alpinia officinarum Hance & củ & riềng & galanga & galanga (petit) \\
\hline Curcuma longa L. & củ & nghệ & turmeric & $\begin{array}{l}\text { safron des } \\
\text { Indes }\end{array}$ \\
\hline Zingiber officinale Roscoe & củ & gừng & ginger & gingembre \\
\hline
\end{tabular}


